Article

\title{
New Invertebrate Vectors for PST, Spirolides and Okadaic Acid in the North Atlantic
}

\author{
Marisa Silva ${ }^{1,2}$, Aldo Barreiro ${ }^{1,2}$, Paula Rodriguez ${ }^{3}$, Paz Otero ${ }^{3}$, Joana Azevedo ${ }^{2,4}$, \\ Amparo Alfonso ${ }^{3}$, Luis M. Botana ${ }^{3}$ and Vitor Vasconcelos ${ }^{1,2, *}$
}

1 Department of Biology, Faculty of Sciences, University of Porto, Rua do Campo Alegre, Porto 4619-007, Portugal; E-Mails: marisasilva17@gmail.com (M.S.);

aldo.barreiro@gmail.com (A.B.)

2 Center of Marine and Environmental Research-CIMAR/CIIMAR, University of Porto, Rua dos Bragas 289, Porto 4050-123, Portugal; E-Mail: joana_passo@hotmail.com

3 Department of Pharmacology, Faculty of Veterinary, University of Santiago of Compostela, Lugo 27002, Spain; E-Mails: paula.rodriguez17@rai.usc.es (P.R.); mariapaz.otero@rai.usc.es (P.O.); amparo.alfonso@usc.es (A.A.); Luis.Botana@usc.es (L.M.B.)

4 Department of Chemical and Biomolecular Sciences, School of Health and Technology of Porto, Vila Nova de Gaia 4400-330, Portugal

* Author to whom correspondence should be addressed; E-Mail: vmvascon@fc.up.pt; Tel.: +351-223-401-814; Fax: +351-223-390-608.

Received: 22 February 2013; in revised form: 17 April 2013 / Accepted: 10 May 2013 / Published: 5 June 2013

\begin{abstract}
The prevalence of poisoning events due to harmful algal blooms (HABs) has declined during the last two decades through monitoring programs and legislation, implemented mainly for bivalves. However, new toxin vectors and emergent toxins pose a challenge to public health. Several locations on the Portuguese coast were surveyed between 2009 and 2010 for three distinct biotoxin groups [saxitoxin (PST), spirolide (SPX) and okadaic acid (OA)], in 14 benthic species of mollusks and echinoderms. Our main goals were to detect new vectors and unravel the seasonal and geographical patterns of these toxins. PSTs were analyzed by the Lawrence method, SPXs by LC-MS/MS, and OA by LC-MS/MS and UPLC-MS/MS. We report 16 new vectors for these toxins in the North Atlantic. There were differences in toxin contents among species, but no significant geographical or seasonal patterns were found. Our results suggest that legislation should be adjusted to extend the monitoring of marine toxins to a wider range of species besides edible bivalves.
\end{abstract}


Keywords: new vectors; PST; okadaic acid; spirolides; North Atlantic

\section{Introduction}

The occurrence of harmful algal blooms (HABs) has been increasing globally throughout the 20th century [1]. Rising water temperature and eutrophication were pointed out as the most significant factors in this increase [2]. HABs have a severe impact on the economy and human health, because phycotoxins may travel along the food chain, contaminating edible shellfish, resulting in intoxication incidents [3-7]. These phycotoxins can be classified as being either hydrophilic or lipophilic, with typical molecular weights (MW) of $500 \mathrm{Da}$ and $600 \mathrm{Da}$, respectively [8]. Besides commercially important bivalves, other organisms, such as crustaceans, gastropods and fish, have been reported as phycotoxin vectors [9-11]. HAB poisoning events have been sporadic worldwide during the past two decades. The establishment of legislation, mostly for edible bivalves and monitoring programs are of extreme importance for poisoning prevention [7,12,13].

Paralytic shellfish toxins (PSTs) are a group of alkaloids that cause Paralytic Shellfish Poisoning (PSP). Intoxication events caused by these toxins result from the ingestion of contaminated shellfish [4,5]. These alkaloids are comprised of saxitoxin (STX) plus 57 analogs that bind specifically to site 1 of voltage-gated $\mathrm{Na}^{+}$channels (Nav), causing paralysis. Currently, there is no antidote available. Ventilation support plus fluid therapy are the only treatments available [14]. After the first report in the USA in 1920, PSTs have been reported all over the globe [4,5]. The main producers of these neurotoxins are several species of dinoflagellates (Alexandrium sp., Gymnodinium catenatum and Pyrodinium bahamense var. compressum), as well as certain brackish and freshwater cyanobacteria (Anabaena circinalis, A. lemmermannii, Aphanizomenon gracile, A. issatschenkoi, Rivularia sp., Lynbya wolleii, Planktothrix sp. and Cylindrospermopsis raciborskii) [15-19]. The European Food Safety Authority (EFSA), proposes the use of toxicity equivalency factors (TEFs) as a unit that integrates all PST analogues for their conversion to SXT equivalents [14]. Fourteen TEF values have been calculated based on acute intra peritoneal (i.p.) toxicity in mice: $\mathrm{NEO}=1 ; \mathrm{GTX}_{1}=1$; dc-STX $=1$; $\mathrm{GTX}_{4}=0.7 ; \mathrm{GTX}_{3}=0.6 ; \mathrm{GTX}_{2}=0.4 ;$ dc-NeoSTX $=0.4 ;$ dc-GTX $3=0.4 ; 11$-hydroxy-STX $=0.3$; dc-GTX $\mathrm{GT}_{2}=0.2 ; \mathrm{GTX}_{5}=0.1 ; \mathrm{GTX}_{6}=0.1 ; \mathrm{C}_{2}=0.1 ; \mathrm{C}_{4}=0.1$ [14]. There are only 15 standards available as certified material. In 2009, EFSA established the acute reference dose (ARfD) for PSTs as $0.5 \mu \mathrm{g}$ STX equivalents $/ \mathrm{kg}$ body weight, due to the lack of repeated oral intake data of these toxins in humans and animals [14]. The guideline limit value for PSTs is $800 \mathrm{ng}$ SXT equivalents/g shellfish meat [20].

Spirolides (SPXs) belong to the group of the cyclic imines that includes other compounds, like gymnodimines, pinnatoxins, pteriatoxins, symbioimines, prorocentrolides and spiro-prorocentrolides [21,22]. These marine toxins have a cyclic imine group that is responsible for their neurotoxicity. SPXs bind specifically to both the muscarinic and nicotinic acetylcholine receptors (mAChR and nAChR, respectively) in the central and peripheral nervous system [23]. These biotoxins have acute toxicity by i.p. and oral administration in mouse bioassays (MBAs); however, there have been no reports of poisoning incidents $[23,24]$. SPXs have already been reported in microalgae and 
shellfish in Canada [25-27], Scotland [28], USA [29], Norway [30], Italy [31], Denmark [21], France [32], Spain [33] and Chile [34]. Other cyclic imines seem to be confined to warmer waters of the Pacific Ocean, with reports from Japan, China and New Zealand [23,35]. SPXs are produced by dinoflagellate species, such as Alexandrium ostenfeldii and A. peruvianum [36]. The $\mathrm{C}$ group is the most toxic among SPXs and the only one with certified material available [37]. There are no legislated limits for cyclic imines, due to the lack of toxicological data [38].

Okadaic acid (OA) and its derivatives, dinophysistoxin-1 and 2 (DTX-1, DTX-2), are responsible for Diarrheic Shellfish Poisoning (DSP). This group of neurotoxins is composed of polyethers that inhibit type 1 and 2A serine/threonine phosphatases [39]. OA and its analog, DTX-1, are also tumor promoters [40]. DSP incidents have been reported all over the globe [41-44]. Several species of phytoplankton have already been reported as causing DSP, particularly from the genera Phalacroma, Prorocentrum and Dinophysis [45-49]. The accepted limit established in Europe is $160 \mathrm{ng}$ OA equivalents/g shellfish meat [20].

The occurrence of emergent toxins and new vectors in the Atlantic Ocean brings new challenges for monitoring programs. It is necessary to fill the lack of knowledge and improve monitoring programs in order to minimize risks to human health. Close monitoring, in conjunction with reliable detection methods, helps to reduce the number of poisonings. Benthic organisms are generally poorly studied regarding their role as potential vectors for marine toxins, with the exception of bivalves [3-5,7,13,26,37]. Several benthic species were surveyed in this study, including gastropods (sea-snails, sea-slugs and limpets), bivalves (mussels) and echinoderms (starfishes and sea-urchins). We have chosen these particular species, because most of them are edible and we strongly believe that the human health risk is underestimated. In addition, all of them play an important role in benthic food-chains. Our aims were to unravel new vectors of PST, OA and SPX, to study the existence of seasonal, geographical and interspecific patterns of toxin accumulation. Table 1 shows the species sampled in this work and their trophic level, edibility and monitoring status.

Table 1. Species sampled and their trophic level, edibility and monitoring status.

\begin{tabular}{ccccc}
\hline Species & Trophic level & Edibility & Monitored & References \\
\hline Gibbula sp. & Grazer & Yes & No & {$[20,50]$} \\
Monodonta sp. & Grazer & Yes & No & {$[20,50]$} \\
Littorina sp. & Grazer & Yes & No & {$[20,50]$} \\
Patella intermedia & Grazer & Yes & No & {$[20,51]$} \\
Paracentrotus lividus & Grazer & Yes & No & {$[20,52]$} \\
Echinus esculentus & Grazer & Yes & No & {$[20,53]$} \\
Aplysia depilans & Grazer & No & No & {$[20,54]$} \\
Mytilus galloprovincialis & Filter feeder & Yes & Yes & {$[20,51]$} \\
Nucella lapillus & 1st level Predator & Yes & No & {$[20,51]$} \\
Marthasterias glacialis & 2nd level Predator & No & No & {$[20,51]$} \\
Charonia lampas & 3rd level Predator & Yes & No & {$[20,55]$} \\
\hline
\end{tabular}




\section{Results and Discussion}

\subsection{PSTs}

In 104 samples analyzed, we obtained 51\% positive results. A sample was considered positive when the toxin levels detected were above the limit of detection (LOD); however, $30.2 \%$ of these samples were below the limit of quantification (LOQ) for SXT and its analogs (Figure 1). Regarding gastropods, bivalves and echinoderms, most of the positive results occurred in the late spring-summer season. In the general linear model, significant differences were not detected for any of the fixed factors: sampling site $\left(F_{11,90}=1.9 ; p=0.08\right)$ or species $\left(F_{9,92}=1.8 ; p=0.09\right)$. These results can be explained by the high resemblance between species average values, although there were differences in their dispersion. It should be noted that the average PST concentration was in general very low (Figure 2). The percentage of analogs in each group screened (Figure 3) shows that the most toxic groups, carbamate (STX, NEO, GTX1, GTX2, GTX3 and GTX4) and decarbamoyl (dcSTX, dcGTX1, dcGTX2, dcGTX3 and dcGTX4), were always present in all species [14]. The former group was the most common, since $67 \%$ of the positives have carbamate forms, constituting $50 \%-83 \%$ of the PSTs' total content. The decarbamoyl group contributes from $50 \%$ to $67 \%$ of the total toxin content in the majority of the positive samples. The less toxic $N$-sulfo-carbamoyl group (C1, C2, C3, C4, GTX5 and GTX6) was only detected in $33 \%$ of the positive samples, reaching a maximum of $20 \%$ of the total PST content.

Figure 1. Paralytic shellfish toxin (PST) content in saxitoxin (STX) $2 \mathrm{HCl}$ equivalent $\mathrm{ng} / \mathrm{g}$ fresh weight (fw) in all groups: (A) bivalves—Mytilus galloprovincialis; (B) echinodermsMarthasterias glacialis and Paracentrotus lividus; (C) gastropods-Nucella lapillus; Charonia lampas; Monodonta turbinata; Monodonta lineata; Gibbula umbilicalis and Aplysia depilans. Limit value for PSTs is $800 \mathrm{ng}$ SXT equivalents/g shellfish meat.

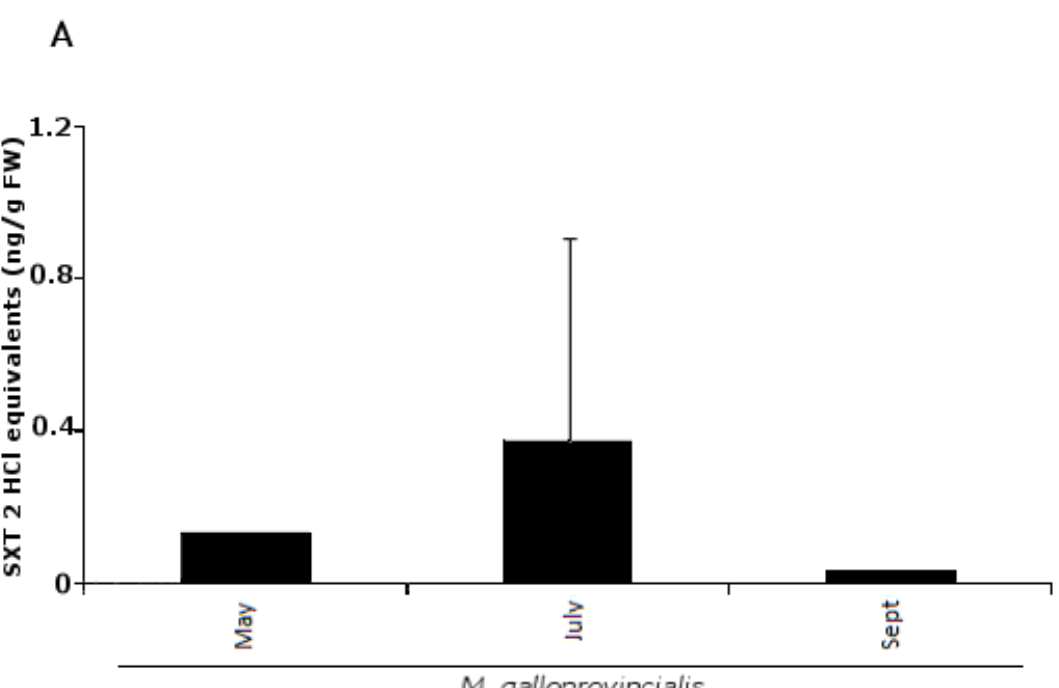


Figure 1. Cont.

B

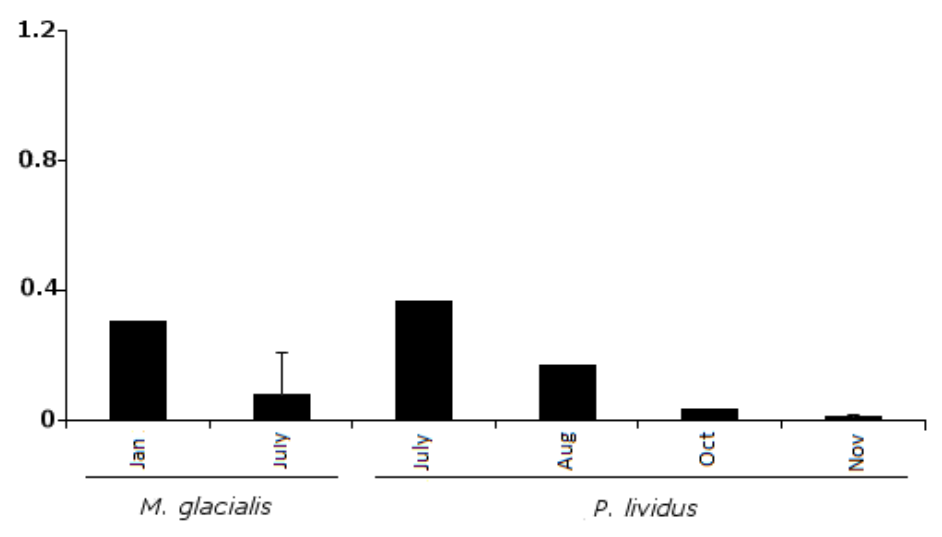

C

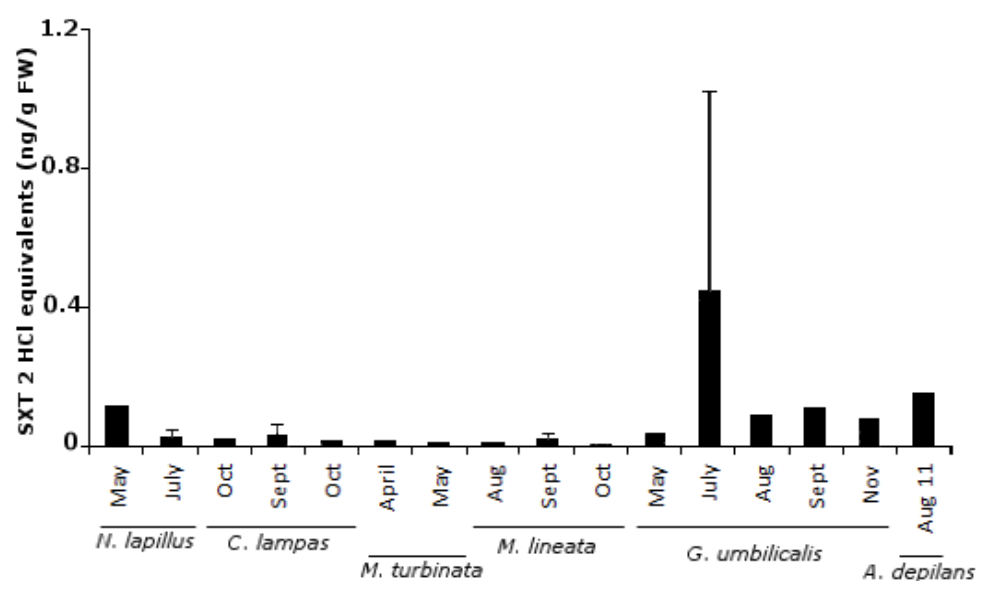

Figure 2. Box and whisker plots for PST concentrations [SXT $\mathrm{HCl} 2$ equivalents (ng/g fw)] found in each species (C. la.-C. lampas; G. um.-G. umbilicalis; M. ga.-M. galloprovincialis; M. gl.-M. glacialis; M. li.-M. lineata; M. tu.-M. turbinata; N. la.-N. lapillus; P. in.-P. intermedia; P. li.-P. lividus). Limit value for PSTs is $800 \mathrm{ng}$ SXT equivalents/g shellfish meat.

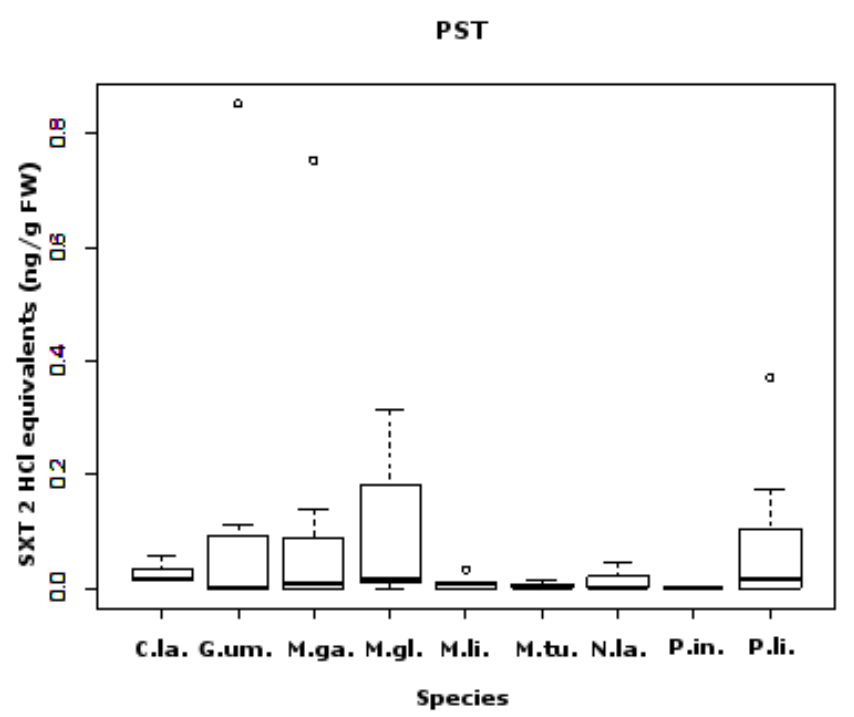


Figure 3. PST profiles in each group screened.

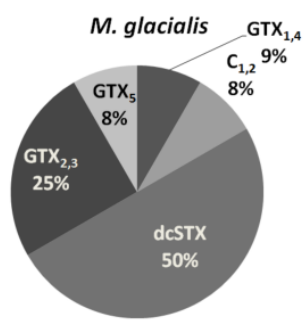

G. umbilicalis

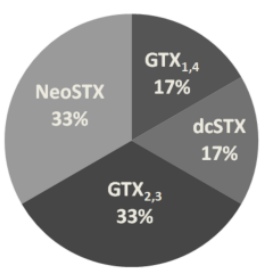

A. depilans

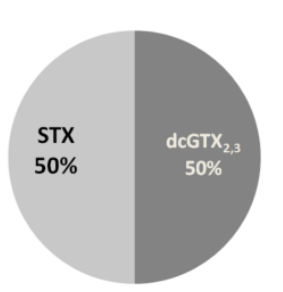

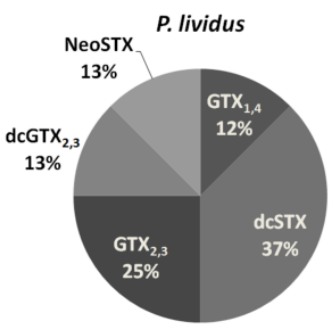

M. turbinata

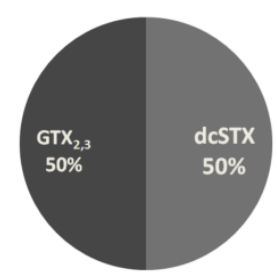

C. lampas

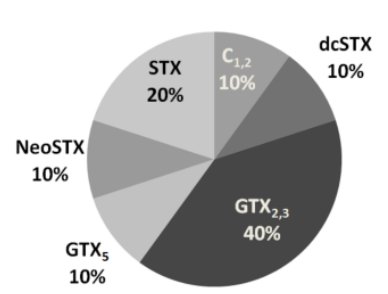

M. galloprovincialis

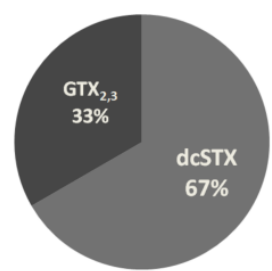

M. lineata

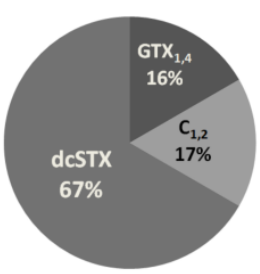

N. Iapillus

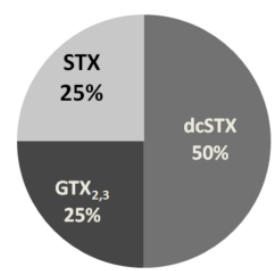

In all the species, positives were below the limit implemented in Europe [20]. In comparison with recent work performed on the Portuguese coast [4], the present toxin profile detected was wider, showing a higher prevalence of the most potent analogs. However, the detected concentrations were lower. There was no previous data available regarding PSTs on the Portuguese coast in taxa other than bivalves $[13,56]$. PST metabolism in bivalves is very complex, since some species show the ability to convert low toxic forms to high toxic ones, therefore presenting different toxin profile than the producers [57-59]. Gastropods are known for their ability to accumulate PSTs and having low depuration rates and, thus, being quite dangerous to humans, since they remain toxic for long periods of time. Most poisoning events due to gastropod ingestion have been reported in Eastern Asia [9,11]. Regarding bivalves, M. galloprovincialis has $67 \%$ of its PSTs as dcSTX, with the remainder being $\mathrm{GTX}_{2,3}$ (Figure 3). This profile could be due either to a high carbamoylase activity or feeding on more toxic dinoflagellate species [9], in contrast to a previous work [13], which showed mussels with a toxin profile enriched in the less toxic groups. There is evidence that GTX analogs can be converted into SXT in shellfish, due to the action of bacteria [60], and mediated by glutathione (GSH) [61]. This could be the reason why the mussel predator, $N$. lapillus, has $25 \%$ of SXT. Nevertheless, grazer gastropods can also acquire PSTs directly [62]. This is the case with Monodonta sp., G. umbilicalis and $A$. depilans, with the latter showing a higher toxin content (50\% STX). Gibbula umbilicalis had $30 \%$ of NEO, and in Monodonta species, the carbamate group was absent (Figure 3). Charonia lampas is a scavenger and a predator, so it most probably acquired PSTs indirectly. In comparison with other works, the levels found in this species were low [63]. Although PSTs have already been detected in echinoderms, namely in starfish [64,65], the report of PSTs in sea-urchins is a novelty. Comparing the toxin content of both species, M. glacialis had $84 \%$ of its toxin content as carbamate analogs, while 
P. lividus had 50\%, which could be due to a dietary effect. Asakawa et al. (1997) [64] found higher concentrations of PSTs in the starfish Asterias amurensis; however, in this work, we detected a higher diversity and concentration of the carbamate group.

Our data show six new PST vectors among the species screened: four gastropods (G. umbilicalis, N. lapillus, Monodonta sp. and A. depilans) and two echinoderms (P. lividus, M. glacialis).

\section{2. $O A$}

A total of $51 \%$ of 55 samples were positive for OA (>LOD), with $14.3 \%$ of these below LOQ. No analogs were detected. Most of the positives (61.5\%), as well as the higher concentrations detected in the late spring-summer season (Figure 4). The average concentration found for each species ranged between $0.58 \mathrm{ng} / \mathrm{g}$ fw (in C. lampas) and $175.71 \mathrm{ng} / \mathrm{g}$ fw (N. lapillus). Statistically significant differences for sampling site were detected, although they were close to the limit of statistical significance $\left(F_{8,43}=2.4 ; p=0.049\right)$. This was possibly due to the fact that $\mathrm{OA}$ had a greater proportion of positive results and higher toxin concentration. It is possible that a greater sampling effort for PSTs and SPX could result in significant $p$-values for the sampling site as well. For species, clear significant differences were found $\left(F_{8,43}=2.4 ; p<0.001\right)$.

Figure 4. Okadaic acid (OA) positive results (ng/g fw) for all sampled groups of organisms: (A) bivalves; (B) echinoderms; (C) gastropods. Y-axis in logarithmic scale. Limit value (LV) established in Europe is $160 \mathrm{ng}$ OA equivalents (eq)/g shellfish meat (s.m.).

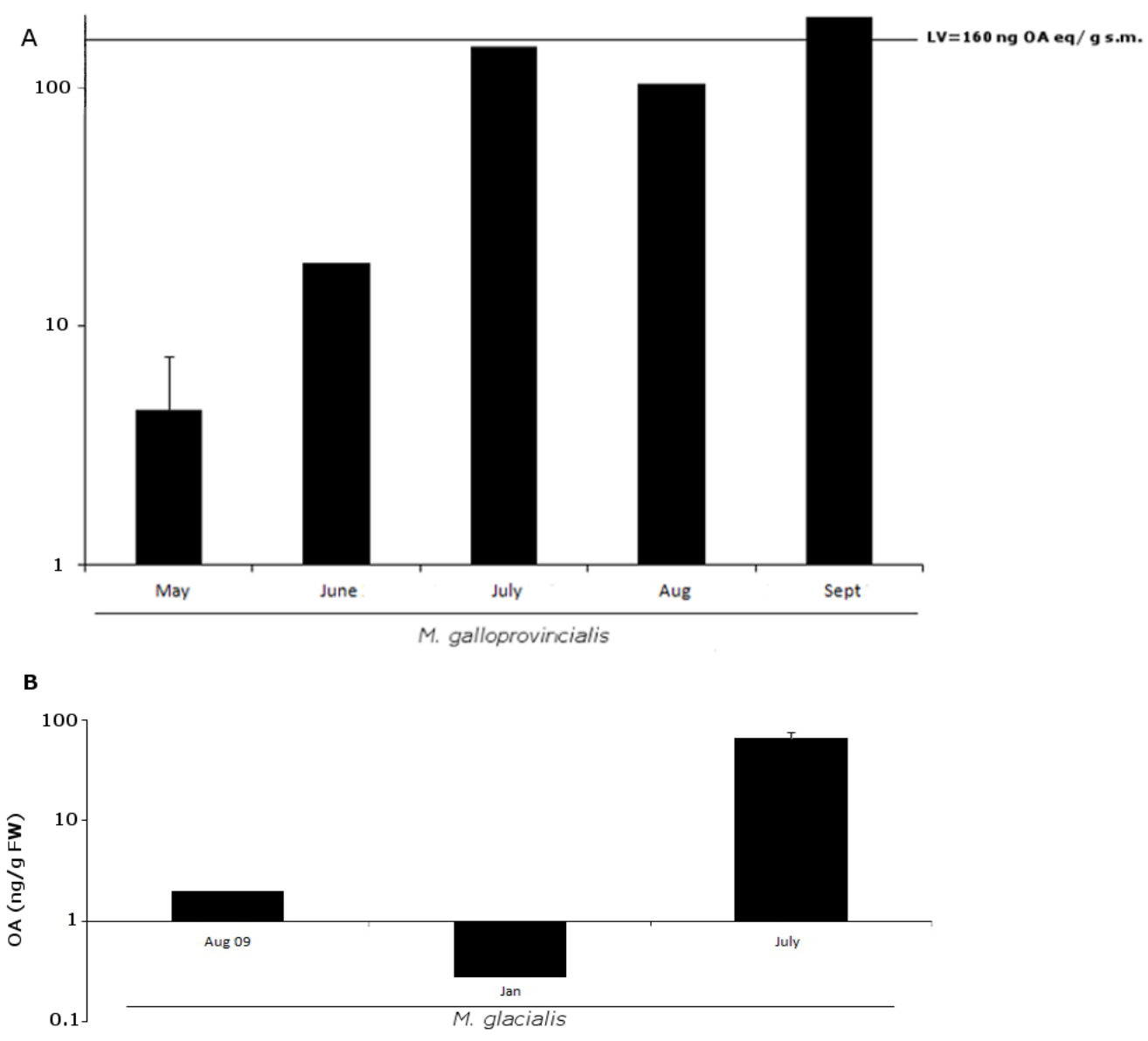


Figure 4. Cont.

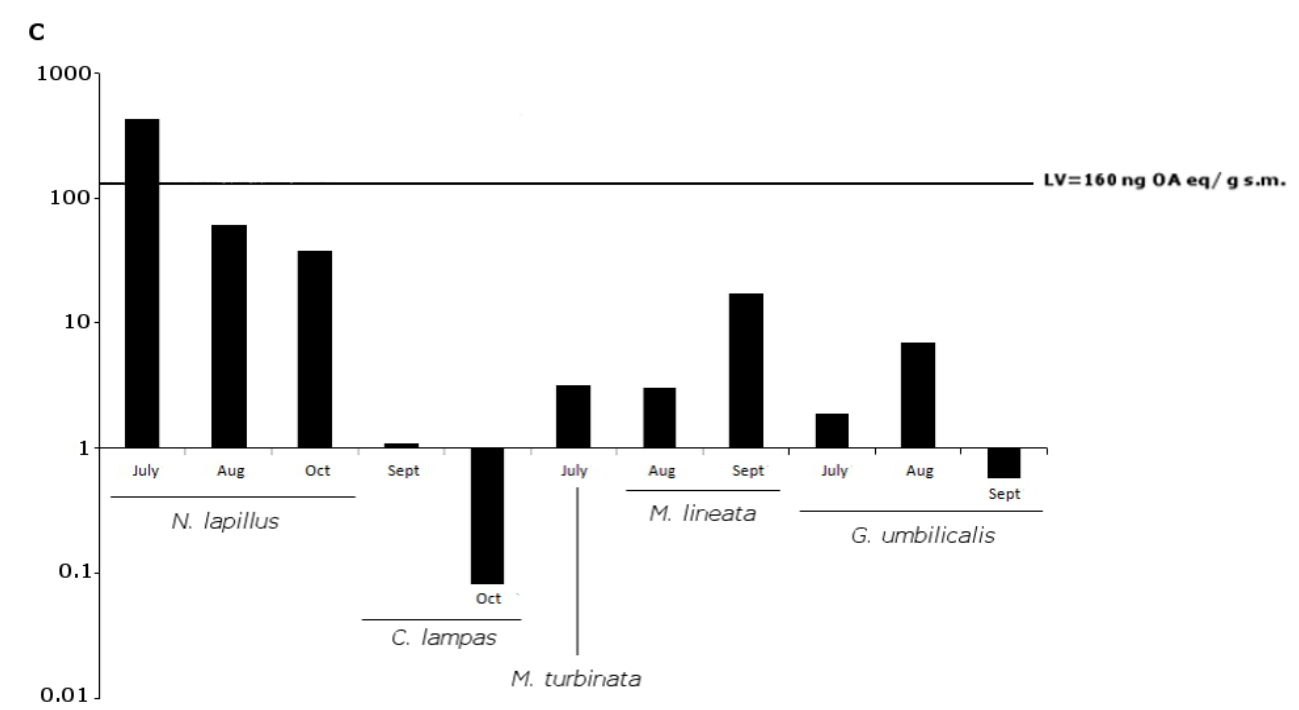

The majority of significant differences in pairwise comparisons between species appeared in this group of toxins. Differences were due to two major groups; those that have the lowest average OA values (six species-C. lampas, G. umbilicalis, M. lineata, M. turbinata, P. lividus, P. intermedia) versus those that have the highest average values (three species-M. glacialis, M. galloprovincialis, $N$. lapillus) (see Figure 5 and Table 2). Interestingly, the species with highest average OA values are linked through the food chain, with M. galloprovincialis being predated by $N$. lapillus and both by M. glacialis (Figure 6) [51]. We show five first reports of OA in G. umbilicalis, N. lapillus, Monodonta sp., P. lividus and M. glacialis. These results suggest the need for a revision of marine toxin monitoring policies in order to consider the inclusion of groups other than bivalves. In addition, the highest concentration detected did not occur in bivalves, but in the edible gastropod, $N$. lapillus.

Figure 5. Box and whisker plots of OA concentrations (ng/g fw) found in each species (C. la.-C. lampas; G. um.-G. umbilicalis; M. ga.-M. galloprovincialis; M. gl.-M. glacialis; M. li.-M. lineata; M. tu.-M. turbinata; N. la.-N. lapillus; P. in.-P. intermedia; P. li.-P. lividus). Limit value (LV) established in Europe is $160 \mathrm{ng}$ OA equivalents (eq)/g shellfish meat (s.m.).

OA

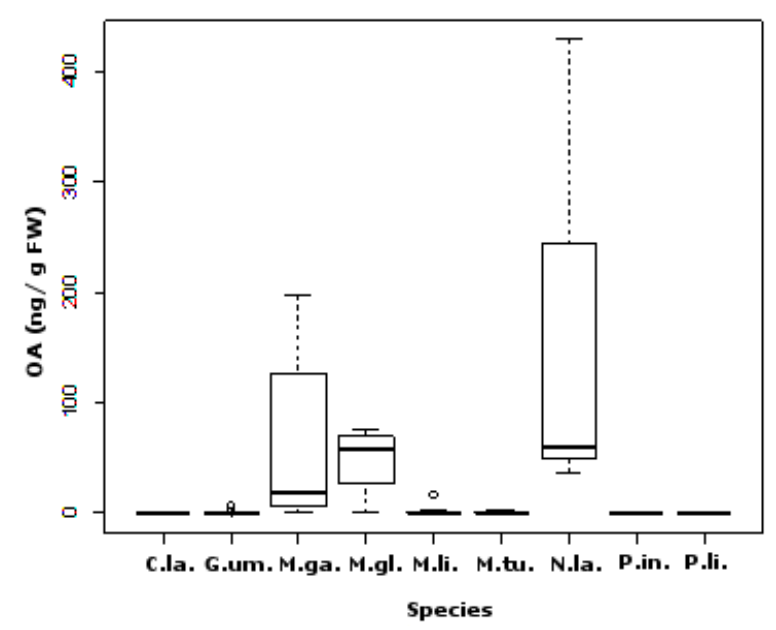


Table 2. Species' OA concentration pairwise comparisons using post hoc Tukey test.

\begin{tabular}{ccc}
\hline Species pairwise comparisons & $\boldsymbol{z}$ & $\boldsymbol{p}$ \\
\hline N. lapillus-C. lampas & 3.3 & 0.03 \\
M. glacialis-G. umbilicalis & 3.8 & $<0.01$ \\
M. galloprovincialis-G. umbilicalis & 5.2 & $<0.001$ \\
N. lapillus-G. umbilicalis & 4.7 & $<0.001$ \\
M. lineata-M. glacialis & -3.6 & $<0.01$ \\
M. turbinata-M. glacialis & -3.4 & 0.02 \\
P. lividus - M. glacialis & -5.6 & $<0.001$ \\
P. intermedia-M. glacialis & -5.5 & $<0.001$ \\
M. galloprovincialis-M. lineata & 4.8 & $<0.001$ \\
N. lapillus $-M$. lineata & 4.6 & $<0.001$ \\
M. galloprovincialis-M. turbinata & 4.1 & $<0.01$ \\
N. lapillus $-M$. turbinata & 4.0 & $<0.01$ \\
P. lividus-M. galloprovincialis & -7.1 & $<0.001$ \\
P. intermedia-M. galloprovincialis & -6.4 & $<0.001$ \\
P. lividus $-N$. lapillus & -6.4 & $<0.001$ \\
P. intermedia-N. lapillus & -5.9 & $<0.001$ \\
P. intermedia-P. lividus & -0.6 & $<0.001$ \\
\hline
\end{tabular}

Figure 6. Trophic relation between M. galloprovincialis, $N$. lapillus and M. glacialis.

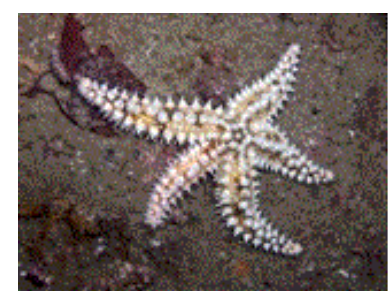

M. glacialis

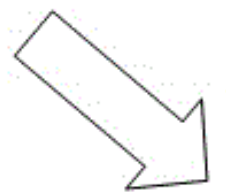

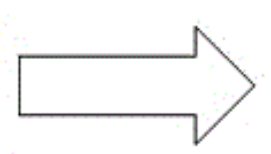

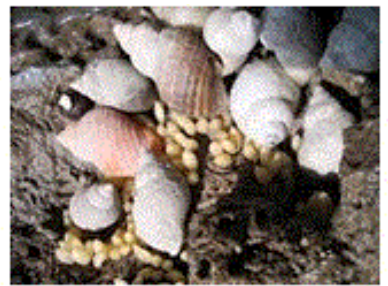

N. lapillus

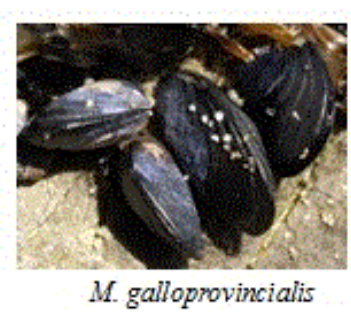

Two samples exceeded the $160 \mathrm{ng}$ OA equivalents/g limit [20]: N. lapillus collected in July 2010 in Memória with $429.41 \mathrm{ng} / \mathrm{g} \mathrm{fw}$ and M. galloprovincialis collected in September 2010 from the same site with $198.17 \mathrm{ng} / \mathrm{g}$ fw. Our average OA levels detected were similar to other reports on the Portuguese coast [13]. We detected OA in January, which seemed to be unusual [13], but this could be explained by our wider range of species screened.

\subsection{3-Desmethyl Spirolide C}

In 55 samples analyzed, $38.2 \%$ of the results were positive for 13-desmethyl Spirolide C (Figure 7). A sample was considered positive when the toxin levels detected were above the LOD. Concentrations 
ranged between $0.49 \mathrm{ng} / \mathrm{g}$ fw and $3.86 \mathrm{ng} / \mathrm{g}$ fw. Approximately half (48\%) of the positive results occurred in the late spring-summer season. Concentrations were also higher in this period (Figure 7).

Figure 7. SPX positive results (ng/g fw) for all sampled groups of organisms.

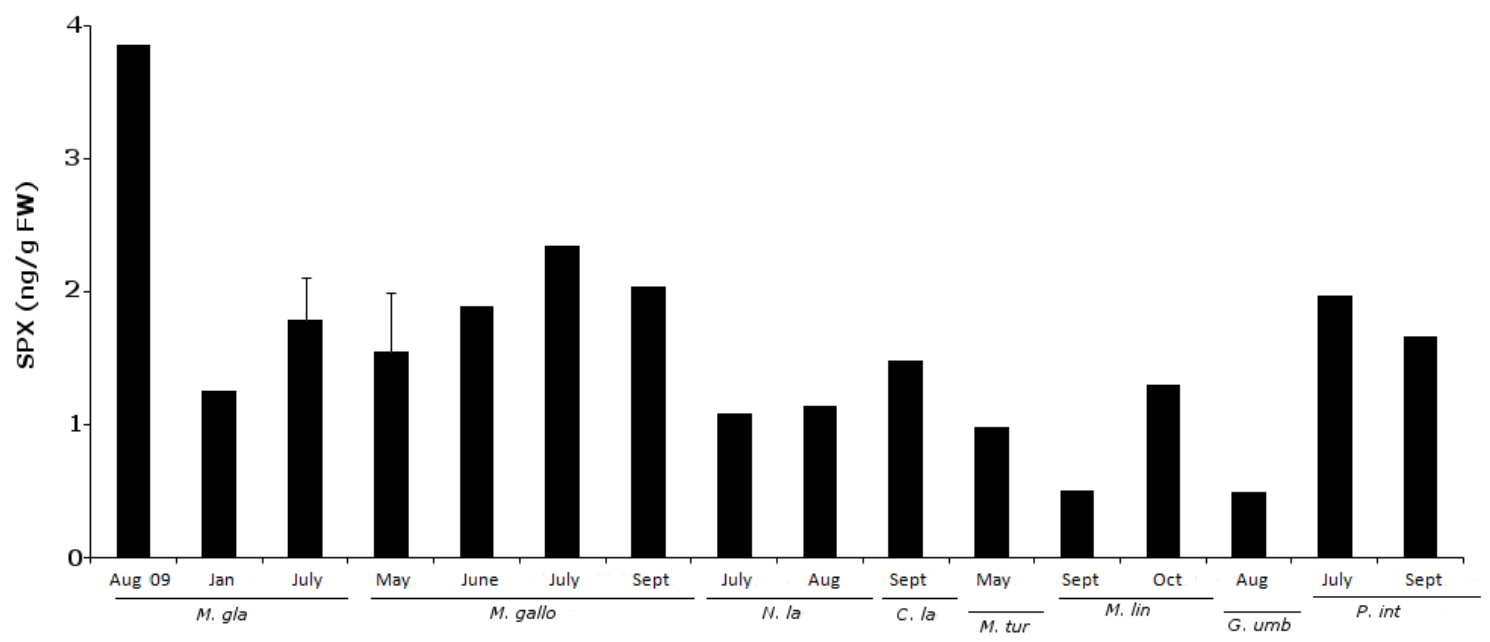

Regarding SPX toxin concentrations, significant differences were found for between species, but not for sampling sites. Here, as for OA, differences in pairwise comparisons were due to the same differentiated groups, with the exception of the species $C$. lampas and $P$. intermedia, as shown in Figure 8. Both species showed a large dispersion (see Table 3). We have shown five first reports for this biotoxin in G. umbilicalis, $N$. lapillus, Monodonta sp., M. glacialis and P. intermedia. It is important to point out that this is not only the first report of SPX in these species, but also on the Portuguese coast. SPX showed a wide range of dispersion, not only geographical, but also in terms of vectors.

Figure 8. Box and whisker plots of SPX concentration (ng/g fw) found in each species (C. la.-C. lampas; G. um.-G. umbilicalis; M. ga.-M. galloprovincialis; M. gl.-M. glacialis; M. li.-M. lineata; M. tu.-M. turbinata; N. la.-N. lapillus; P. in.-P. intermedia; P. li.-P. lividus).

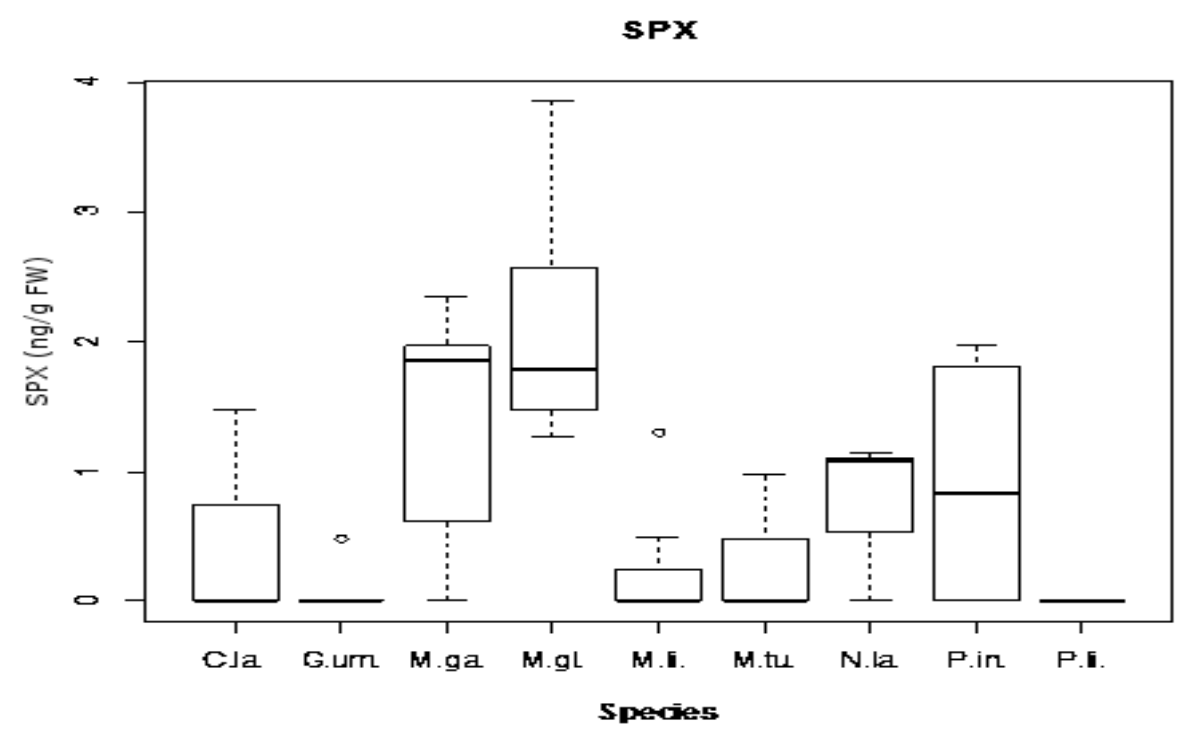


Table 3. Species' SPX concentration pairwise comparisons using post hoc Tukey test.

\begin{tabular}{ccc}
\hline Species pairwise comparisons & $\boldsymbol{z}$ & $\boldsymbol{p}$ \\
\hline M. glacialis-G. umbilicalis & 4.3 & $<0.001$ \\
M. galloprovincialis-G. umbilicalis & 3.2 & 0.02 \\
M. lineata-M. glacialis & -3.9 & $<0.01$ \\
M. turbinata-M. glacialis & -3.5 & 0.01 \\
P. lividus-M. glacialis & -4.2 & $<0.001$ \\
P. lividus - M. galloprovincialis & -3.1 & 0.04 \\
\hline
\end{tabular}

\subsection{Toxins Concentrations Found: Comparison between Species and Sampling Sites}

The results of the MANOVA test show that there were clear significant differences between species $\left(F_{8,42}=2.4 ; p<0.001\right)$ and small differences between sampling sites $\left(F_{8,42}=1.7 ; p=0.04\right)$. These were, in general, the same results as those from the analysis for each individual toxin. In the pairwise multivariate comparisons performed with the Hotelling test, generally, the species that showed more significant differences regarding toxin concentrations were M. glacialis, M. galloprovincialis and $N$. lapillus. The previous Tukey tests showed a similar pattern, i.e., the same pairs of species showed the most significant differences (see Table 4). With respect to sampling site, differences between sites were, as expected, from the test for individual toxins, mainly due to OA (Table 4). However, if the sampling effort was more balanced, differences between sampling sites could also be detected for PSTs and SPX. Memória was the most intensively sampled site and showed more differences in this test. It should be noted that the species with the highest toxin concentrations are linked by the food-chain. Mytilus galloprovincialis is predated by both N. lapillus and M. glacialis, while the latter also preys on $N$. lapillus $[51,66]$. The advantage of this multivariate test is that our data support the possibility of bioaccumulation of toxins along the food chain, taking into account all toxins together.

Table 4. Pairwise comparisons between factor levels of sampling site and species, using the three groups of toxins as dependent factors.

\begin{tabular}{cc}
\hline Pairwise Comparison & $\boldsymbol{p}$ \\
\hline C. lampas-P. intermedia & 0.01 \\
G. umbilicalis-M. glacialis & $<0.001$ \\
G. umbilicalis-M. galloprovincialis & 0.03 \\
G. umbilicalis-N. lapillus & $<0.01$ \\
P. intermedia-M. glacialis & $<0.001$ \\
P. intermedia-M. galloprovincialis & 0.02 \\
P. intermedia-N. lapillus & $<0.001$ \\
M. lineata-M. glacialis & 0.01 \\
M. turbinata-M. glacialis & $<0.01$ \\
M. galloprovincialis-P. lividus & $<0.001$ \\
P. lividus-M. glacialis & 0 \\
P. lividus-N. lapillus & \\
Angeiras-Memória & 0.03 \\
Memória-Porto Côvo & 0.01 \\
Memória-Viana do Castelo & 0.03 \\
Memória-Almograve & 0.01 \\
\hline
\end{tabular}




\section{Experimental Section}

\subsection{Selected Species and Sampling Points}

In this study, we were searching for unconventional vectors of marine toxins, so we surveyed several benthic species. We focused our sampling on edible species, but also other species that play an important role in the food-chain: gastropods (Monodonta lineata, Monodonta turbinata, Gibbula umbilicalis, Gibbula magus, Littorina littorea, Littorina saxatilis, Nucella lapillus, Patella intermedia, Aplysia depilans, Charonia lampas), bivalves (Mytilus galloprovincialis), sea-urchins (Paracentrotus lividus, Echinus esculentus) and starfish (Marthasterias glacialis).

Animals were collected monthly from several locations along the northern and southern Portuguese coast (Figure 9) from July 2009 till the end of 2010. Samples of Charonia lampas were purchased in local markets from the same areas. Organisms were collected from the intertidal area during low tides and were transported to the laboratory in refrigerated containers. If they were not processed immediately, they were frozen at $-20{ }^{\circ} \mathrm{C}$. The number of samples collected and average number of specimens needed to set a pooled sample are detailed in Table 5.

Figure 9. Location of the sampling points on the Atlantic Portuguese coast: 1: Viana do Castelo; 2: Esposende; 3: Póvoa do Varzim; 4: Angeiras; 5: Memória; 6: Valadares; 7: Aguda; 8: São Martinho do Porto; 9: São Torpes; 10: Porto Côvo; 11: Monte Clérigos; 12: Vila Nova de Milfontes; 13: Almograve.

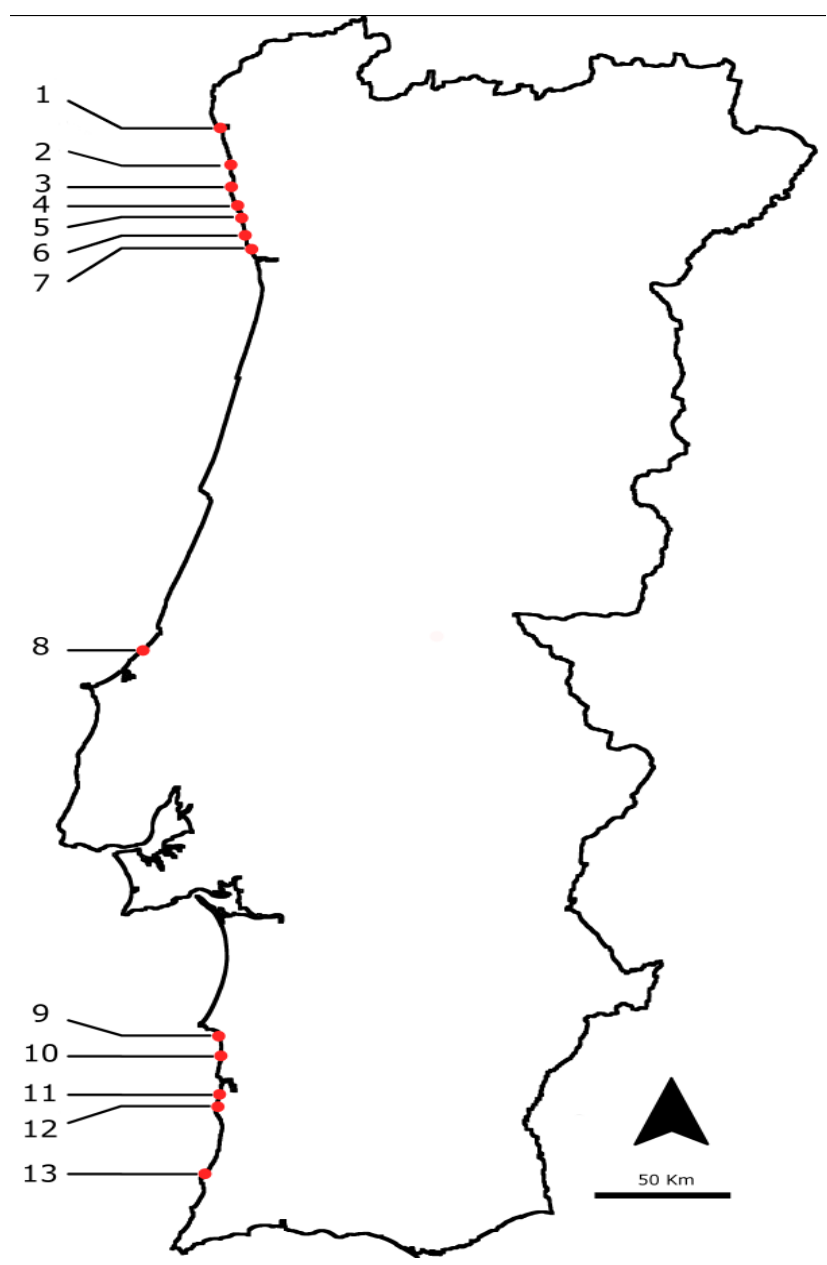


Table 5. Average number of specimens comprising a pooled sample and number of samples collected since July 2009 till 2010. Availability of animals is dependent on their geographical distribution and ecology.

\begin{tabular}{ccc}
\hline Species & $\begin{array}{c}\text { Number of pooled samples collected } \\
\text { from July 2009 till end 2010 }\end{array}$ & $\begin{array}{c}\text { Average number of animals } \\
\text { collected to set a pooled sample }\end{array}$ \\
\hline Gibbula umbilicalis & 34 & 100 \\
Gibbula magus & 1 & 90 \\
Monodonta lineata & 20 & 86 \\
Monodonta turbinata & 21 & 86 \\
Nucella lapillus & 13 & 15 \\
Littorina littorea & 2 & 10 \\
Littorina saxatilis & 4 & 15 \\
Patella intermedia & 4 & 15 \\
Charonia lampas & 5 & 1 \\
Mytilus galloprovincialis & 7 & 30 \\
Paracentrotus lividus & 10 & 10 \\
Marthasterias glacialis & 8 & 1 \\
Echinus esculentus & 2 & 1 \\
Aplysia depilans & 1 & 1 \\
\hline
\end{tabular}

\subsection{Sample Preparation}

\subsubsection{Paralytic Shellfish Toxin (PST) Extraction}

Samples were extracted following the Lawrence et al. method [67]. Animals were dissected and homogenized with a blender (A320R1, $700 \mathrm{~W}$, Moulinex) in pooled groups in order to obtain $1 \mathrm{~g}$ of extractable tissue, with the exception of Charonia lampas, Marthasterias glacialis, Echinus esculentus and Aplysia depilans, which were treated individually. The homogenized tissue was extracted with $3 \mathrm{~mL} \mathrm{1 \%}$ acetic acid (Merck, Portugal) using a vortex mixer for $5 \mathrm{~min}$ (Top Mix 1118, Fisher Scientific, Portugal), then heated in a boiling water bath for $10 \mathrm{~min}$, remixed on a vortex mixer and placed in ice for $5 \mathrm{~min}$. The resulting mixture was sonicated $(1 \mathrm{~min}, 70 \mathrm{~Hz}$, Vibra Cell, Sonic \& Materials, USA) and subsequently centrifuged at $4495 \times \mathrm{g}$ for $10 \mathrm{~min}$ at $4{ }^{\circ} \mathrm{C}$ (Centrifugal-Legend RT, Sorvall). Then, $2 \mathrm{~mL}$ of $1 \%$ acetic acid was added to the centrifuge tube containing the solid residue, mixed well on a vortex mixer and centrifuged again $\left(4495 \mathrm{~g} / 10 \mathrm{~min} / 4{ }^{\circ} \mathrm{C}\right)$. The supernatant solution was collected pooled into the same tube that contained the first portion of extract and finally diluted to $5 \mathrm{~mL}$ with $1 \%$ acetic acid. An aliquot $(1 \mathrm{~mL})$ of the crude extract was passed through a $\mathrm{C} 18$ solid-phase extraction (SPE) cartridge (500 mg/3 mL volume from Supelco, Bellefonte, PA, USA), previously conditioned with $10 \mathrm{~mL}$ methanol (Fisher Scientific, Leics, UK), followed by $10 \mathrm{~mL}$ water (MilliQ). Toxin was absorbed onto the column and eluted at a flux of $0.4 \mathrm{~mL} / \mathrm{min}$ using $2 \mathrm{~mL}$ of ultrapure water. The $\mathrm{pH}$ was adjusted to $6.5 \mathrm{using} 0.2 \mathrm{M} \mathrm{NaOH}$ (Sigma Aldrich, Portugal). The eluents were evaporated to dryness (Acid-resistant Centrivap Concentrator, Labconco, MO, USA) and dissolved in $0.5 \mathrm{~mL}$ of $0.03 \mathrm{M}$ acetic acid. The extracts were passed through $0.45 \mu \mathrm{m}$ filters (Ultrafree-MC centrifugal filter devices from Millipore, Spain) and pre-oxidized before HPCL-FLD analysis. The extracts were oxidized with hydrogen peroxide and periodate (Panreac Quimica, Spain). Peroxide oxidation consisted of mixing $25 \mu \mathrm{L}$ 
of $10 \%$ hydrogen peroxide in water (v/v) with $250 \mu \mathrm{L} 1 \mathrm{M} \mathrm{NaOH}$ and $100 \mu \mathrm{L}$ of sample. The solution was then mixed on a vortex mixer and rested at room temperature for $2 \mathrm{~min}$. Then $20 \mu \mathrm{L}$ of acetic acid was added. At this point, the solution was homogenized and $25 \mu \mathrm{L}$ was injected into the HPLC system. Peroxide oxidant solution was prepared daily. Periodate oxidation consisted of mixing $100 \mu \mathrm{L}$ sample with $100 \mu \mathrm{L}$ of deionized water and $500 \mu \mathrm{L}$ periodate oxidant. The solution reacted for 1 min at room temperature before the addition of $5 \mu \mathrm{L}$ of acetic acid. Periodate oxidant was prepared daily by mixing $5 \mathrm{~mL}$ of $0.03 \mathrm{M}$ periodic acid with $5 \mathrm{~mL}$ of $0.3 \mathrm{M}$ ammonium formate and $5 \mathrm{~mL}$ of $0.3 \mathrm{M}$ sodium phosphate dibasic. The $\mathrm{pH}$ of the final solution was adjusted to 8.2 with $1 \mathrm{M} \mathrm{NaOH}$.

\subsubsection{Lipophilic Toxins Extraction}

The protocol from Otero et al. (2010) [68] was followed for the extraction of okadaic acid (OA), dinophysistoxin (DTX-1 and DTX-2) and spirolides (13,19-didesmethyl SPX C; 13-desmethyl SPX C). Animals were dissected and homogenized with the help of a blender (A320R1, $700 \mathrm{~W}$, Moulinex) in pooled groups in order to obtain $1 \mathrm{~g}$ of extractable tissue, with the exception of Charonia lampas, Marthasterias glacialis, Echinus esculentus and Aplysia depilans. In these cases, each animal was treated separately. The $1 \mathrm{~g}$ of homogenized tissue was extracted with $3 \mathrm{~mL}$ of methanol (Fisher Scientific), then centrifuged during $10 \mathrm{~min}$ at $2932 \mathrm{~g}$ at $4{ }^{\circ} \mathrm{C}$ (Centrifugal-Legend RT). This procedure was repeated twice, and the supernatants combined and concentrated to dryness (Acid-resistant Centrivap Concentrator, Labconco). Residues were then re-suspended in $10 \mathrm{~mL}$ of water (MilliQ) and partitioned twice against dichloromethane (Merck). The organic layers $(20 \mathrm{~mL})$ were reserved and concentrated by drying and re-suspended in $1 \mathrm{~mL}$ of methanol. Then $500 \mu \mathrm{L}$ was concentrated to dryness, re-suspended in $100 \mu \mathrm{L}$ of methanol and filtered through a $0.45 \mu \mathrm{m}$ filter (UltraFree-MC centrifugal devices, Millipore) before LC-MS/MS analysis.

\subsection{Sample Analysis}

\subsubsection{PSP HPLC-FLD Conditions}

The conditions were the same as reported by Rodriguez et al. (2010) [69]. Briefly, the analyses were performed using high-performance liquid chromatography with fluorescence detection (HPLC-FLD) equipment (Waters 2695), consisting of a pump (Waters 515) and a column (SupelcosilTM LC-18, $5 \mu \mathrm{m}, 15 \times 4.6 \mathrm{~mm}$, Sigma Aldrich) kept at $35^{\circ} \mathrm{C}$. Empower software (Waters, Manchester, UK) was used to control the process. Toxins were detected with a Waters 2475 fluorescence detector, with excitation set to $340 \mathrm{~nm}$ and emission to $395 \mathrm{~nm}$. Injection volume was $25 \mu \mathrm{L}$. Eluent (A) of the mobile phase was composed by $0.1 \mathrm{M}$ of ammonium formate (Sigma Aldrich). Eluent (B) was composed by $0.1 \mathrm{M}$ of ammonium formate in 5\% of acetonitrile (Panreac Quimica). Both eluents had their $\mathrm{pH}$ adjusted to 6 with $1 \mathrm{M}$ acetic acid. The gradient started with 5\% of mobile phase (B) for the first $5 \mathrm{~min}$, then increasing to $70 \%$ up to $\min 9$, then decreasing to $0 \%$ in min 11 and stayed in $0 \%$ till the end of the run $(15 \mathrm{~min})$. The flow rate was $1 \mathrm{~mL} / \mathrm{min}$. For toxin detection and determination, standards of SXT, decarbamoyl gonyautoxin 2 and 3 (dcGTX and $_{2}$ $\left.\operatorname{dcGTX}_{3}\right)$ and decarbamoylsaxitoxin (dcSXT) combined (Mix I), gonyautoxin 2 and $3\left(\mathrm{GTX}_{2}\right.$ and GTX $\left._{3}\right)$, gonyautoxin $5\left(\mathrm{GTX}_{5}\right)$ and sulfo-carbamoyl saxitoxin 1 and $2\left(\mathrm{C}_{1}\right.$ and $\left.\mathrm{C}_{2}\right)$ combined (Mix II) 
were pre-oxidized with hydrogen peroxide and neosaxitoxin (NEO), gonyautoxin 1 and 4 (GTX G $_{1}$ and $\mathrm{GTX}_{4}$ ) combined (Mix III) were oxidized with periodate. Standards were obtained from NRC Certified Reference Material Program (Institute for Marine Biosciences, Halifax, Canada). The three mixtures of standards were diluted 10 -fold in water (MilliQ), a calibration curve was made with subsequent dilutions in water with five points for each mixture. Concentrations ranging from $6 \mathrm{ng} / \mathrm{mL}$ to $257 \mathrm{ng} / \mathrm{mL}$ for Mix I, from $8 \mathrm{ng} / \mathrm{mL}$ to $354 \mathrm{ng} / \mathrm{mL}$ for Mix II and from $6 \mathrm{ng} / \mathrm{mL}$ to $290 \mathrm{ng} / \mathrm{mL}$ for Mix III. Every calibration solution was made daily for each set of analysis. PSTs were identified by comparison of oxidation products of the standards retention times. PSTs were quantified by direct comparison of peak areas with the calibration curves. Quantified levels for each analog must be converted in STX $2 \mathrm{HCl}$ equivalents $\mathrm{ng} / \mathrm{g}$, using applied TEFs for each analog [14]. Retention times were: $\operatorname{dcGTX}_{2,3}$ (3.75 and $\left.4.05 \mathrm{~min}\right), \mathrm{C}_{1,2}$ (5.2 $\left.\mathrm{min}\right)$, dcSTX (7.06 and $\left.7.92 \mathrm{~min}\right), \mathrm{GTX}_{2,3}(9.17 \mathrm{~min}$ ), $\operatorname{GTX}_{5}(10.6 \mathrm{~min})$, SXT $(11.8 \mathrm{~min})$ and NEO $(8.05 \mathrm{~min})$ (Figure 10). Due to the complexity of the samples and to overcome the matrix effect, non-oxidized samples of each species were injected in the HPLC. Blanks were prepared daily. The limits of detection (LOD) and quantification (LOQ) for the HPLC-FLD are displayed in Table 6.

Figure 10. Chromatograms of the PSTs standards and a positive sample for M. glacialis, hydroxylated toxins are oxidized with periodate and non-hydroxylated toxins with peroxide. (A) Standards injected with periodate oxidation, peak $\operatorname{GTX}_{1,4}(1)$ and $\operatorname{GTX}_{1,4}(3)$ are secondary oxidation products of $\operatorname{GTX}_{1,4}$. Peaks $\mathrm{NEO}(1)$ and $\mathrm{NEO}(3)$ are secondary oxidation products of NEO. (B) Standards injected with peroxide oxidation.

(C) Chromatogram of a positive sample in $M$. glacialis injected with periodate oxidation.

(D) Chromatogram of a positive sample in M. glacialis injected with peroxide oxidation.

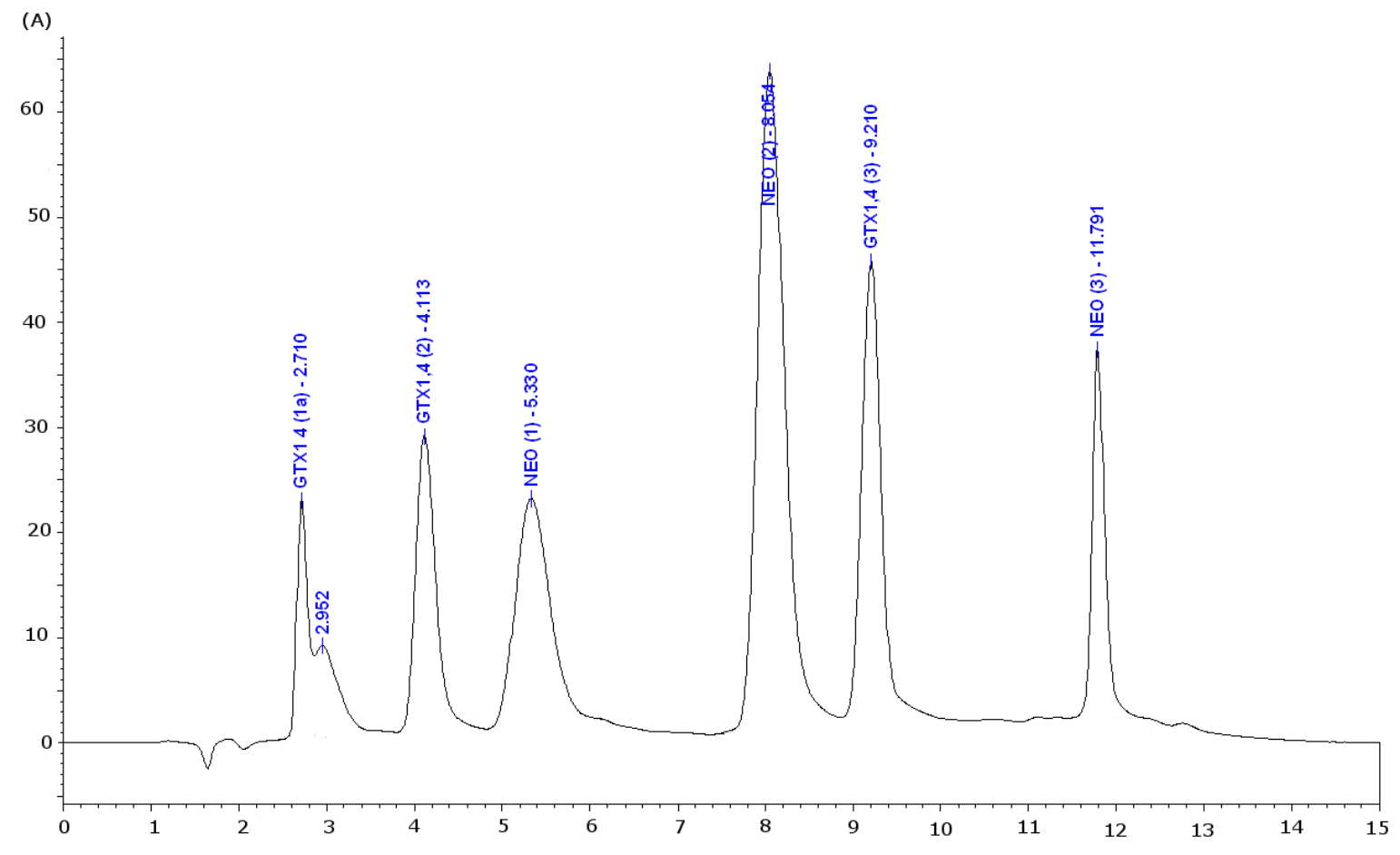


Mar. Drugs 2013, 11

1951

Figure 10. Cont.
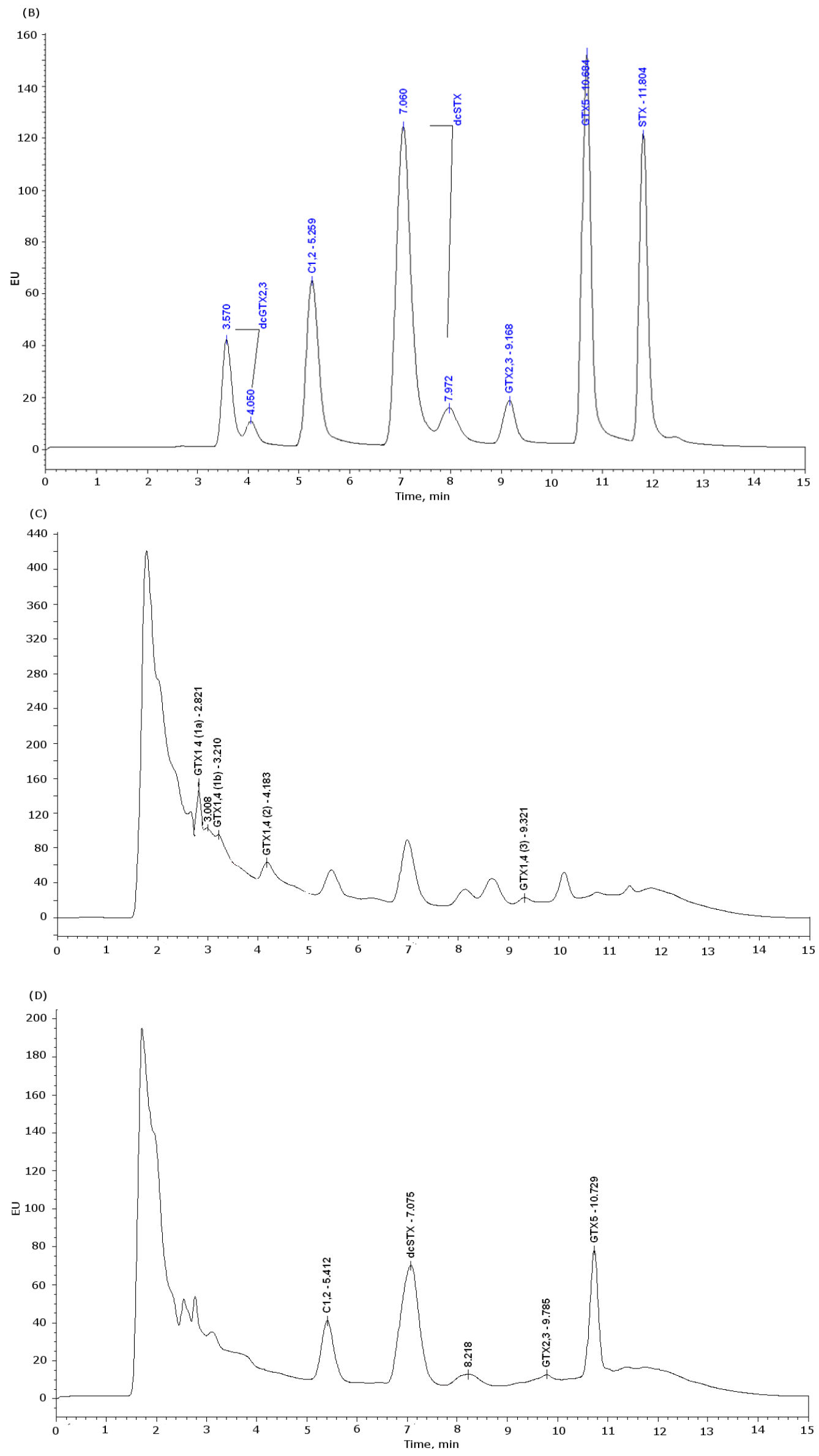
Table 6. Limits of detection (LODs) and quantification (LOQs) of the method for each toxin (expressed in $\mathrm{ng} / \mathrm{mL}$ ).

\begin{tabular}{ccc}
\hline Toxin & LOD & LOQ \\
\hline $\operatorname{dcGTX}_{2,3}$ & 2.7 & 8 \\
$\mathrm{C}_{1,2}$ & 3 & 11 \\
$\operatorname{dcSTX}_{\mathrm{GTX}_{2,3}}$ & 0.2 & 6 \\
$\mathrm{GTX}_{5}$ & 1.5 & 9 \\
$\mathrm{SXT}$ & 0.4 & 8 \\
$\mathrm{GTX}_{1,4}$ & 0.4 & 7 \\
$\mathrm{NEO}$ & 3 & 9 \\
& 1.2 & 8 \\
\hline
\end{tabular}

\subsubsection{Lipophilic Toxins LC-MS/MS Conditions}

The LC-MS/MS conditions were the same as reported in Otero et al. (2011) [70]. Briefly, the analyses were performed with high-performance liquid chromatography (LC) equipment (Shimadzu, Kyoto, Japan) consisting of a binary system of LC-10ADVP pumps, an autoinjector (SIL-10ADVP) with degasser (DGU-14A), refrigerated rack, column oven (CTO-10ACvp) and a system controller (SCL-10Avp). The LC system was coupled to a hybrid quadrupole-linear ion trap mass spectrometer (MS) (2000 QTRAPLC/MS/MS, Applied Biosystems, Carlsbad, CA, USA), equipped with an atmospheric pressure ionization unit (API) and fitted with an electrospray ionization source (ESI). The equipment operated in the conventional mode of low energy of collision induced dissociation (CID) of MS/MS. Nitrogen was produced by a Nitrocraft $\mathrm{NC}_{\mathrm{LC} / \mathrm{MS}}$ generator from Air Liquide (Madrid, Spain). The LC system operated with the ESI interface using the following parameters: curtain gas, 15 psi; collision-activated dissociation gas (CAD), 6 psi; IonSpray voltage, $4000 \mathrm{~V}$; temperature, $450{ }^{\circ} \mathrm{C}$; gas 1, 50 psi; gas 2, 50 psi. Analyst software was used to control the whole process. Toxins separation was performed with a BDS-Hypersil-C8 column (i.d. $2 \times 50 \mathrm{~mm} ; 3 \mu \mathrm{m}$ ) and a guard cartridge (i.d. $10 \times 2.1 \mathrm{~mm}$ ) from Thermo (Waltham, MA, USA). Column oven temperature was set at $25^{\circ} \mathrm{C}$. Injection volume of $5 \mu \mathrm{L}$. Eluent A of the mobile phase was composed of $50 \mathrm{mM}$ formic acid (Merck, Madrid, Spain) and $2 \mathrm{mM}$ ammonium formate (Sigma Aldrich, Madrid, Spain) in water. Eluent B consisted of acetonitrile (Panreac Quimica, Barcelona, Spain) in water (95:5) with ammonium formate $(2 \mathrm{mM})$ and formic acid $(50 \mathrm{mM})$. The gradient started with $30 \%-90 \%$ of mobile phase (B) for $8 \mathrm{~min}$, then maintained at $90 \%$ until min 11 , decreasing to $30 \%$ over 0.5 min and maintained during 5.5 min until the end of the run. Flow rate was $0.2 \mathrm{~mL} / \mathrm{min}$. The mass spectrometer was operated in multiple reaction monitoring (MRM), detecting in positive and negative modes. Two product ions were analyzed per compound, one for quantification and another for confirmation. The transitions employed were: OA and DTX-2 $(m / z$ 803.5 > 255.5/113.5), DTX-1 $(m / z$ 817.5 > 255.5/113.5), 13,19-didesmethyl SPX C $(m / z 678.5>660.5 / 430.5), 13$-desmethyl SPX C $(m / z 692.5>674.4 / 444.4)$. Retention times were: OA (8.2 min), DTX-1 (9.7 min), DTX-2(8.7 min), 13,19-didesmethyl SPX C (4 min) and 13-desmethyl SPX C (5.6 min). For the calibration curve, eight different concentrations of the standard (Laboratorios Cifga, Spain) were injected in duplicate: OA/DTX-1/DTX-2 from $1 \mathrm{ng} / \mathrm{mL}$ to $200 \mathrm{ng} / \mathrm{mL}$; SPX from $0.5 \mathrm{ng} / \mathrm{mL}$ to $200 \mathrm{ng} / \mathrm{mL}$ (Figure 11). All toxins were quantified, using their peak areas to calculate amounts and using the curve obtained from each standard. The LOD and LOQ of the LC-ESI-CID-MS/MS 
for each toxin were: OA/DTX-1/DTX-2 $(4 / 10 \mathrm{ng} / \mathrm{mL})$ and SPX $(0.1 / 0.5 \mathrm{ng} / \mathrm{mL})$. Due to technical reasons, the LC-MS/MS device was not available, so the analyses for DSP's proceeded in a UPLC-MS/MS (50 samples of 55).

Figure 11. Mass chromatograms of the LC-ESI-CID-MS/MS obtained under multiple reaction monitoring (MRM): (A) extracted ion chromatogram (XIC) of OA standard (200 ng/mL), $m / z \quad 803.5>255.5 / 113.5$; (B) XIC of 13-desmethyl SPX C standard (200 ng/mL), $m / z 692.4>674.4 / 444.4$; (C) XIC of a positive sample for OA in N. lapillus $(\mathrm{m} / z 803.5>255.5 / 113.5)$; (D) XIC of a positive sample for 13-desmethyl SPX C in N. lapillus $(\mathrm{m} / \mathrm{z} 692.4>674.4 / 444.4)$.
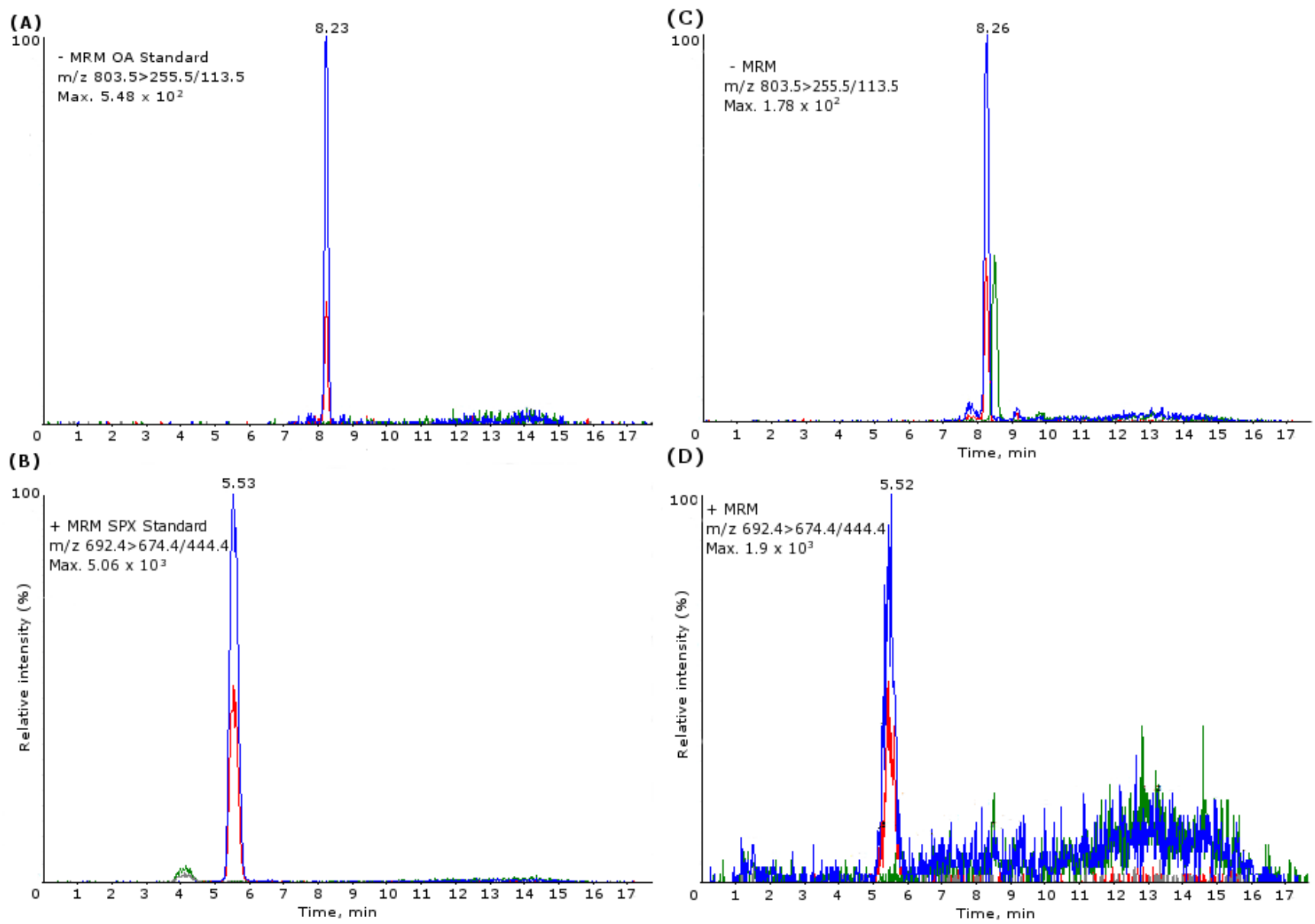

\subsubsection{Lipophilic Toxin UPLC-MS/MS Conditions}

Samples were analyzed according to Otero et al. (2011) [70] with the ultra-high performance liquid chromatography equipment, ACQUITY UPLC system, coupled to a Xevo TQ MS mass spectrometer from Waters (Manchester, UK). The apparatus was equipped with a multimode source ESI/APCI/ESCi, a vacuum system with two air-cooled Edwards Vacuum turbo molecular pumps and one Varian rotary backing pump. The nitrogen generator was a Nitrocraft NCLC/MS from Air Liquide (Madrid, Spain). Chromatographic separation and detection of OA and its derivatives was performed with a Waters Acquity UPLC BEH $\mathrm{C}_{18}$ column $(100 \mathrm{~mm} \times 2.1,1.7 \mu \mathrm{m})$ with an in-line $0.2 \mu \mathrm{m}$ Acquity UPLC filter. The column oven was set at $30^{\circ} \mathrm{C}$. Eluent A consisted of water, and eluent B contained acetonitrile 
(Panreac Quimica, Spain) and water (95:5). Both eluents contained $2 \mathrm{mM}$ ammonium formate (Sigma Aldrich, Spain) and $50 \mathrm{mM}$ formic acid (Merck, Spain). The gradient program used to elute the toxins started with $30 \%$ mobile phase B for 3 min, increasing to $90 \%$ B over $1.5 \mathrm{~min}$, then kept stable for 1 min and reducing to $30 \%$ of $\mathrm{B}$ over the next $0.1 \mathrm{~min}$ and finally kept for 2 min before the next injection. The flow rate was $0.4 \mathrm{~mL} / \mathrm{min}$, and the injection volume was $5 \mu \mathrm{L}$. The Xevo TQ MS mass spectrometer operated with the following optimized source-dependent parameters (ESI source): capillary potential $2.5 \mathrm{kV}$, cone voltage $20 \mathrm{~V}$, desolvation temperature $350{ }^{\circ} \mathrm{C}$, desolvation gas flow $850 \mathrm{~L} / \mathrm{h} \mathrm{N}$, cone gas flow $50 \mathrm{~L} / \mathrm{h} \mathrm{N}_{2}$, source temperature $120^{\circ} \mathrm{C}$ and collision gas flow $20 \mathrm{~V}$. Argon was used as the collision gas at $4.5 \times 10^{-3}$ mbar. The mass spectrometer operated in MRM, detecting in negative mode, analyzing two product ions per compound, one for quantification another for confirmation. The transitions employed were the same used in the LC-MS/MS device; retention times were $2.91 \mathrm{~min}$ for OA, $3.08 \mathrm{~min}$ for DTX-2 and $3.52 \mathrm{~min}$ for DTX-1. For the calibration curve, several dilutions of the standards (Laboratorios Cifga) from $1 \mathrm{ng} / \mathrm{mL}$ to $200 \mathrm{ng} / \mathrm{mL}$ were set (Figure 12). OA and its derivatives were quantified using their peak areas to calculate amounts and using the curve obtained from each standard. The LOD and LOQ of the method were: $3.7 / 6.4 \mathrm{ng} / \mathrm{mL}(\mathrm{OA})$, 6/10 ng/mL (DTX-1) and 1.6/5.4 ng/mL (DTX-2).

Figure 12. Mass chromatograms of the UPLC-MS/MS obtained under MRM operation:

(A) total ion chromatogram (TIC) of OA standard $200 \mathrm{ng} / \mathrm{mL}, \mathrm{m} / z$ 803.5 > 255.5/113.5;

(B) TIC of a positive sample for OA in M. glacialis, $m / z$ 803.5 $>255.5 / 113.5$.

(A)

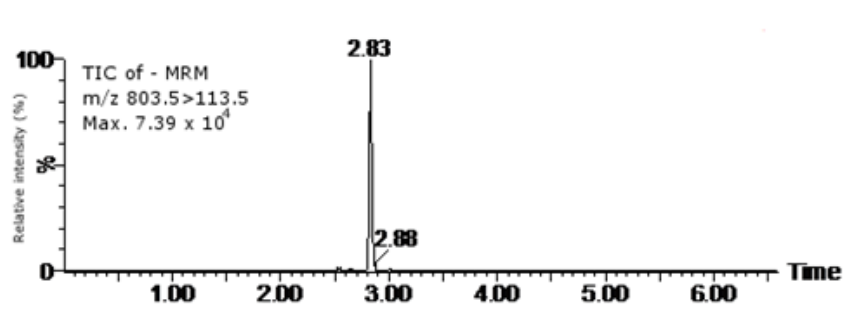

(B)

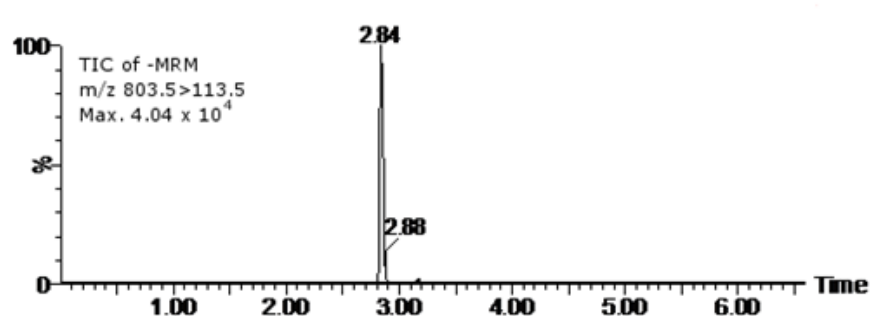

\subsection{Statistical Analyses}

Analyses were performed using R (version 2.14.1) software. In order to test for differences in toxin content for each group of toxins, a general linear mixed model was fitted using toxin concentration as the dependent variable and species and sampling site as additive fixed factors. Seasonal patterns were visually observed in our data distribution (see results), but because the selected dates did not represent the whole possible seasonal effects, the sampling date was included in the model as a random factor. For those fixed factors that showed significant differences, pairwise comparisons between levels were made with the post hoc Tukey test. Normality was tested on model residuals with the Shapiro test. When needed, data were normalized by transformation with the Box-cox function. In order to test for differences in toxin content for all toxins together, MANOVA tests were performed using toxin concentration as the dependent variable. Species and sampling site were analyzed as fixed factors in separate models. Hotelling tests were performed for pairwise comparisons between the levels of factors that showed significant differences. Data were tested for normality with a multivariate Shapiro test and normalized with the Box-cox function when needed [71]. Some of the datasets analyzed here 
contain unbalanced numbers of samples per factor level (see Table 5). This might compromise the accuracy of linear models with complicated factor structures and should be taken into account when interpreting the significance values reported in the tables.

\section{Conclusions}

In this work, we surveyed the Atlantic continental coast of Portugal for unconventional vectors of three groups of biotoxins-PSTs, OA and SPX. Using HPLC-FLD, LC-MS/MS and UPLC-MS/MS techniques, we were able to detect SPX for the first time on the Portuguese coast and also new vectors for this group of biotoxins. We report 16 new vectors for these toxins in the North Atlantic. The values obtained for some species, such as starfish, M. glacialis, and the gastropod, $N$. lapillus, suggest that toxin transfer along the food chain probably occurred via mussels. There was no significant evidence of geographical patterns in terms of toxin content among the selected species. However, these differences might be found with a stronger sampling effort. The detection of new vectors, particularly those that are potentially used as food resources, suggests that monitoring of marine toxins should be extended to species other than bivalves in order to limit human health risks. The same could be considered for regulated toxins limits, which are usually calculated for edible bivalves, since our study showed that these toxins are bioaccumulated in upper levels of the food chain. We hope that this work contributes towards the establishment of new legislation, especially for cyclic imines.

\section{Acknowledgments}

This work was partially funded by the Project MARBIOTECH (reference NORTE-07-0124FEDER-000047) within the SR \& TD Integrated Program MARVALOR-Building research and innovation capacity for improved management and valorization of marine resources, supported by the Programa Operacional Regional do Norte (ON.2-O Novo Norte) and by the European Regional Development Fund, by the INTERREG IV projects Atlantox, Pharmatlantic, FCT project PesT-C/MAR/LA0015/2011, UP through IJUP projects and FEDER cofunded-grant: From Ministerio de Ciencia y Tecnología, Spain: AGL2012-40485-CO2-01. MS acknowledges FCT, FSE and MCTES for co-funding SFRH/BD/73269/2010, Vitor Ramos, João Paulo Machado and Jonathan Wilson.

\section{References}

1. Hallegraeff, G.M. Algal blooms are not a simple toxic broth. Search 1993, 24, 179.

2. Glibert, P.M.; Anderson, D.; Gentien, P.; Granéli, E.; Sellner, K. The global, complex phenomena of harmful algal blooms. Oceanography 2005, 18, 136-147.

3. Kat, M. The Occurence of Prorocentrum Species and Coincidental Gastrointestinal Illness of Mussel Consumers. In Toxic Dinoflagellate Blooms; Taylor, D.L., Seliger, H.H., Eds.; Elsevier: New York, NY, USA, 1979; pp. 215-220.

4. Rodrigues, S.M.; de Carvalho, M.; Mestre, T.; Ferreira, J.J.; Coelho, M.; Peralta, R.; Vale, P. Paralytic shellfish poisoning due to ingestion of Gymnodinium catenatum contaminated cockles-Application of the AOAC HPLC official method. Toxicon 2012, 59, 558-566.

5. Meyer, K.F.; Sommer, H.; Schoenholz, P. Mussel poisoning. Am. J. Prev. Med. 1928, 2, 365-394. 
6. Steward, I.; Seawright, A.A.; Shaw, G.R. Cyanobacterial Poisoning in Livestock, Wild Mammals and Birds-An Overview. In Cyanobacterial Harmful Algal Blooms: State of Science and Research Needs; Hudnell, H.K., Ed.; Springer: New York, NY, USA, 2008; pp. 613-637.

7. Vale, P.; Antonia, M.; Sampayo, M. Esters of okadaic acid and dinophysistoxin-2 in Portuguese bivalves related to human poisonings. Toxicon 1999, 37, 1109-1121.

8. Gerssen, A.; Pol-Hofstad, I.E.; Poelman, M.; Mulder, P.P.; van den Top, H.J.; de Boer, J. Marine toxins: Chemistry, toxicity, occurrence and detection, with special reference to the Dutch situation. Toxins 2010, 2, 878-904.

9. Deeds, J.R.; Landsberg, J.H.; Etheridge, S.M.; Pitcher, G.C.; Longan, S.W. Non-traditional vectors for paralytic shellfish poisoning. Mar. Drugs 2008, 6, 308-348.

10. Gainey, L.S.J.; Shumway, S. A compendium of the responses of bivalve molluscs to toxic dinoflagellates. J. Shellfish Res. 1988, 7, 623-628.

11. Shumway, S.E. Phycotoxin-related shellfish poisoning: Bivalve molluscs are not the only vectors. Rev. Fish. Sci. 1995, 3, 1-31.

12. Correia, F.S. Um caso raro de intoxicação alimentar colectiva. Bol. Inst. Super. Hig. Doutor Ricardo Jorge 1946, 3, 216-221.

13. Vale, P.; Botelho, M.J.; Rodrigues, S.M.; Gomes, S.S.; Sampayo, M.A.D. Two decades of marine biotoxin monitoring in bivalves from Portugal (1986-2006): A review of exposure assessment. Harmful Algae 2008, 7, 11-25.

14. Alexander, J.; Benford, D.; Cockburn, A.; Cravedi, J.P.; Dogliotti, E.; Di Domenico, A.; Fernández-Cruz, M.L.; Fink-Gremmels, J.; Fürst, P.; Galli, C.; et al. Scientific opinion of the panel on contaminants in the food chain on a request from the European commission on marine biotoxins in shellfish-Saxitoxin Group. EFSA J. 2009, 1019, 1-76.

15. Codd, G.A. Cyanobacterial toxins: Occurrence, properties and biological significance. Water Sci. Technol. 1995, 32, 149-156.

16. Clemente, Z.; Busato, R.H.; Oliveira Ribeiro, C.A.; Cestari, M.M.; Ramsdorf, W.A.; Magalhaes, V.F.; Wosiack, A.C.; Silva de Assis, H.C. Analyses of paralytic shellfish toxins and biomarkers in a southern Brazilian reservoir. Toxicon 2010, 55, 396-406.

17. Carmichael, W.W.; Evans, W.R.; Yin, Q.Q.; Bell, P.; Moczydlowski, E. Evidence for paralytic shellfish poisons in the freshwater cyanobacterium Lyngbya wollei (Farlow ex Gomont) comb. nov. Appl. Environ. Microbiol. 1997, 63, 3104-3110.

18. Ballot, A.; Fastner, J.; Wiedner, C. Paralytic shellfish poisoning toxin-producing cyanobacterium Aphanizomenon gracile in northeast Germany. Appl. Environ. Microbiol. 2010, 76, 1173-1180.

19. Sivonen, K.; Jones, G. Cyanobacterial Toxins. In Toxin Cyanobacteria in Water: A Guide to Their Public Health Consequences, Monitoring and Management; Chorus, I., Bartram, J., Eds.; WHO E \& FN Spon: London, UK, 1999; pp. 41-111.

20. European Commission. Regulation (EC) No. 853/2004 of the European Parliament and of the Council of 29 April 2004 laying down specific hygiene rules for food of animal origin. Available online: http://eur-lex.europa.eu (27 December 2010).

21. Mackinnon, S.L.; Cembella, A.D.; Burton, I.W.; Lewis, N.; LeBlanc, P.; Walter, J.A. Biosyntheis of 13-desmethyl spirolid C by the dinoflagellate Alexandrium ostenfeldii. J. Org. Chem. 2006, 71, 8724-8731. 
22. MacKinnon, S.L.; Walter, J.A.; Quilliam, M.A.; Cembella, A.D.; LeBlanc, P.; Burton, I.W.; Hardstaff, W.R.; Lewis, N.I. Spirolides isolated of the danish strains of the toxigenic dinoflagellate Alexandrium ostenfeldii. J. Nat. Prod. 2006, 69, 983-987.

23. Munday, R. Toxicology of Cyclic Imines: Gymnodimine, Spirolides, Pinnatoxins, Pteriatoxins, Prorocentrolide, Spiro-Prorocentrimine, and Symbioimines. In Seafood and Freshwater Toxins: Pharmacology, Physiology and Detection, 2nd ed.; Botana, L.M., Ed.; CRC Press (Taylor and Francys Group): Boca Raton, FL, USA, 2008; pp. 581-594.

24. Rhodes, L.; Smith, K.; Selwood, A.; McNabb, P.; van Ginkel, R.; Holland, P.; Munday, R. Production of pinnatoxins by a peridinoid dinoflagellate isolated from Northland, New Zealand. Harmful Algae 2010, 9, 384-389.

25. Hu, T.; Curtis, J.M.; Walter, J.A.; Wright, J.L.C. Characterization of biologically inactive spirolides E and F: Identification of the spirolide pharmacophore. Tetrahedron Lett. 1996, 37, 7671-7674.

26. Hu, T.; Curtis, J.M.; Oshima, Y.; Quilliam, M.A.; Walter, J.A.; Watson-Wright, W.M.; Wright, J.L.C. Spirolides B and D, two novel macrocycles isolated from the digestive glands of shellfish. J. Chem. Soc. Chem. Commun. 1995, 20, 2159-2161.

27. Hu, T.; Burton, I.W.; Cembella, A.D.; Curtis, J.M.; Quilliam, M.A.; Walter, J.A.; Wright, J.L. Characterization of spirolides a, c, and 13-desmethyl c, new marine toxins isolated from toxic plankton and contaminated shellfish. J. Nat. Prod. 2001, 64, 308-312.

28. John, U.; Cembella, A.D.; Hummert, C.; Elbrächter, M.; Groben, R.; Medlin, L.K. Discrimination of the toxigenic dinoflagellate species Alexandrium tamarense and Alexandrium ostenfeldii in co-occuring natural populations from Scottish coastal waters. Eur. J. Phycol. 2003, 38, 25-40.

29. Anderson, D.M.; Kulis, D.M.; Keafer, B.A.; Gribble, K.E.; Marin, R.; Scholin, C.A. Identification and enumeration of Alexandrium spp. from the Gulf of Maine using molecular probes. Deep Sea Res. II 2005, 54, 2467-2490.

30. Aasen, J.A.B.; MacKinnon, S.L.; LeBlanc, P.; Walter, J.A.; Hovgaard, P.; Aune, T.; Quilliam, M.A. Detection and identification of spirolides in Norwegian shellfish and plankton. Chem. Res. Toxicol. 2005, 18, 509-515.

31. Ciminiello, P.; Dell'Aversano, C.; Fattorusso, E.; Magno, S.; Tartaglione, L.; Cangini, M.; Pompei, M.; Guerrini, F.; Boni, L.; Pistocchi, R. Toxin profile of Alexandrium ostenfeldii (Dinophyceae) from the Northern Adriatic Sea revealed by liquid chromatography-mass spectometry. Toxicon 2006, 47, 597-604.

32. Amzil, Z.; Sibat, M.; Royer, F.; Masson, N.; Abadie, E. Report on the first detection of pectenotoxin-2, spirolide a and their derivatives in French shellfish. Mar. Drugs 2007, 5, 168-179.

33. Villar Gonzalez, A.; Rodriguez-Velasco, M.L.; Ben-Gigirey, B.; Botana, L.M. First evidence of spirolides in Spanish shellfish. Toxicon 2010, 48, 1068-1074.

34. Álvarez, G.; Uribe, E.; Ávalos, P.; Mariño, C.; Blanco, J. First identification of azaspiracid and spirolides in Mesodesma donacium and Mulinia edulis from Northern Chile. Toxicon 2010, 55, 638-641.

35. Seki, T.; Satake, M.; Mackenzie, A.L.; Kaspar, H.F.; Yasumoto, T. Gimnodimine, a new marine toxin of unprecedented structure isolated from New Zealand oysters and the dinoflagellate, Gymnodinium sp. Tetrahedron Lett. 1995, 36, 7093-7096. 
36. Touzet, N.; Franco, J.M.; Raine, R. Morphogenetic diversity and biotoxin composition of Alexandrium (Dinophyceae) in Irish coastal waters. Harmful Algae 2008, 7, 782-797.

37. Otero, P.; Alfonso, A.; Alfonso, C.; Araoz, R.; Molgo, J.; Vieytes, M.R.; Botana, L.M. First direct fluorescence polarization assay for the detection and quantification of spirolides in mussel samples. Anal. Chim. Acta 2011, 701, 200-208.

38. Alexander, J.; Benford, D.; Boobis, A.; Ceccatelli, S.; Cravedi, J.P.; di Domenico, A.; Doerge, D.; Dogliotti, E.; Edler, L.; Farmer, P.; et al. Scientific Opinion on marine biotoxins in shellfish-Cyclic imines (spirolides, gymnodimines, pinnatoxins and pteriatoxins). EFSA J. 2010, 8, 1628-1887.

39. Bialojan, C.; Takai, A. Inhibitory effect of a marine sponge toxin, okadaic acid, on protein phosphatases. Biochem. J. 1988, 256, 283-290.

40. Maneiro, E.; Rodas, V.L.; Costas, E.; Hernandez, J.M. Shellfish consumption: A major risk factor for colorectal cancer. Med. Hypotheses 2008, 70, 409-412.

41. Elgarch, A.; Vale, P.; Rifai, S.; Fassouane, A. Detection of diarrheic shellfish poisoning and azaspiracid toxins in moroccan mussels: Comparison of the LC-MS method with the commercial immunoassay kit. Mar. Drugs 2008, 6, 587-594.

42. Garcia, C.; Truan, D.; Lagos, M.; Santelices, J.P.; Diaz, J.C.; Lagos, N. Metabolic transformation of dinophysistoxin-3 into dinophysistoxin-1 causes human intoxication by consumption of O-acyl-derivatives dinophysistoxins contaminated shellfish. J. Toxicol. Sci. 2005, 30, 287-296.

43. Scoging, A.; Bahl, M. Diarrhetic shellfish poisoning in the UK. Lancet 1998, 352, 117.

44. Yasumoto, T.; Oshima, Y.; Yamaguchi, M. Occurrence of a new type of shellfish poisoning in tohoku district. Bull. Jpn. Soc. Sci. Fish. 1978, 44, 1249-1255.

45. MacKenzie, L.; Beuzenberg, V.; Holland, P.; McNabb, P.; Suzuki, T.; Selwood, A. Pectenotoxin and okadaic acid-based toxin profiles in Dinophysis acuta and Dinophysis acuminata from New Zealand. Harmful Algae 2005, 4, 75-85.

46. Hu, T.M.; Curtis, J.M.; Walter, J.A.; Wright, J.L.C. Identification of DTX-4, a new water-soluble phosphatase inhibitor from the toxic dinoflagellate Prorocentrum lima. J. Chem. Soc. Chem. Comm. 1995, 5, 597-599.

47. Caroppo, C.; Congestri, R.; Bruno, M. On the presence of Phalacroma rotundatum in the southern Adriatic Sea (Italy). Aquat. Microb. Ecol. 1999, 17, 301-310.

48. Jorgensen, K.; Andersen, P. Relation between the concentration of Dinophysis acuminata and diarrheic shellfish poisoning toxins in blue mussels (Mytilus edulis) during a toxic episode in the Limfjord (Denmark), 2006. J. Shellfish Res. 2007, 26, 1081-1087.

49. Spatharis, S.; Dolapsakis, N.P.; Economou-Amilli, A.; Tsirtsis, G.; Danielidis, D.B. Dynamics of potentially harmful microalgae in a confined Mediterranean Gulf-Assessing the risk of bloom formation. Harmful Algae 2009, 8, 736-743.

50. Crothers, J.H. Common topshells: An introduction to the biology of Osilinus lineatus with notes on other species in the genus. Field Stud. 2001, 10, 115-160.

51. Knox, G.A. Hard Shores. In The Ecology of Seashores; Kennish, M.J., Ed.; CRC Press: Boca Raton, FL, USA, 2001; pp. 20-86.

52. Lemée, R.; Boudouresque, C.F.; Gobert, J.; Malestroit, P.; Mari, X.; Meinesz, A.; Menager, V.; Ruitton, S. Feeding behaviour of Paracentrotus lividus in the presence of Caulerpa taxifolia introduced in the Mediterranean Sea. Oceanol. Acta 1995, 19, 245-253. 
53. Forster, G.R. The ecology of Echinus esculentus L. Quantitative distribution and rate of feeding. J. Mar. Biol. Assoc. UK 1959, 38, 361-367.

54. Carefoot, T.H. Aplysia: Its biology and ecology. Oceanogr. Mar. Biol. Annu. Rev. 1987, 25, 167-284.

55. Lin, S.J.; Hwang, D.F. Possible source of tetrodotoxin in the starfish Astropecten scoparius. Toxicon 2001, 39, 573-579.

56. Vale, P. Hydrolysis of hydroxybenzoate saxitoxin analogues originating from Gymnodium catenatum. Food Chem. 2011, 125, 1160-1165.

57. Ogata, T.; Kodama, M.; Fukuyo, Y.; Inoue, T.; Kamiya, H.; Matsuura, F.; Sekiguchi, K.; Watanabe, S. Studies on paralytic shellfish poisoning in ofunato bay. 1. The occurrence of protogonyaulax spp in Ofunato Bay, in association with the toxification of the scallop Patinopecten yessoensis. Bull. Jpn. Soc. Sci. Fish. 1982, 48, 563-566.

58. Montojo, U.M.; Sakamoto, S.; Cayme, M.F.; Gatdula, N.C.; Furio, E.F.; Relox, J.R.; Sato, S.; Fukuyo, Y.; Kodama, M. Remarkable difference in accumulation of paralytic shellfish poisoning toxins among bivalve species exposed to Pyrodinium bahamense var. compressum bloom in Masinloc bay, Philippines. Toxicon 2006, 48, 85-92.

59. Sekiguchi, K.; Sato, S.; Kaga, S.; Ogata, T.; Kodama, M. Accumulation of paralytic shellfish poisoning toxins in bivalves and an ascidian fed on Alexandrium tamarense cells. Fish. Sci. 2001, 67, 301-305.

60. Asakawa, M.; Takagi, M.; Iida, A.; Oishi, K. Studies on the conversion of paralytic shellfish poison (Psp) components by biochemical reducing agents. Eisei Kagaku 1987, 33, 50-55.

61. Oshima, Y. Chemical and Enzymatic Transformation of Paralytic Shellfish Toxins in Marine Organisms. In Harmful Marine Algal Blooms; Lassus, P., Arzul, G., Erard, E., Gentien, P., Marcaillou, C., Eds.; Lavoisier Intercept Ltd.: Paris, France, 1995; p. 475.

62. Noguchi, T. Marine toxins. Nippon Suisan Gakkaishi 2003, 69, 895-909.

63. Nagashima, Y.; Arakawa, O.; Shiomi, K.; Noguchi, T. Paralytic Shellfish Toxins in a Trumpet Shell. Charonia lampas from Spain. In Harmful and Toxic Algal Blooms; Yasumoto, T., Oshima, Y., Fukuyo, Y., Eds.; Intergovernmental Oceanic Comission of UNESCO: Sendai, Japan, 1996; pp. 425-427.

64. Asakawa, M.; Nishimura, F.; Miyazawa, K.; Noguchi, T. Occurrence of paralytic shellfish poison in the starfish Asterias amurensis in Kure Bay, Hiroshima Prefecture, Japan. Toxicon 1997, 35, 1081-1087.

65. Lin, S.J.; Tsai, Y.H.; Lin, H.P.; Hwang, D.F. Paralytic toxins in Taiwanese starfish Astropecten scoparius. Toxicon 1998, 36, 799-803.

66. Brusca, R.C.; Brusca, G.J. Invertebrates, 2nd ed.; Sinauer Associates, Inc.: Sunderland, MA, USA, 2002.

67. Lawrence, J.F.; Niedzwiadek, B.; Menard, C. Quantitative determination of paralytic shellfish poisoning toxins in shellfish using prechromatographic oxidation and liquid chromatography with fluorescence detection: Collaborative study. J. AOAC Int. 2005, 88, 1714-1732.

68. Otero, P.; Alfonso, A.; Alfonso, C.; Vieytes, M.R.; Louzao, M.C.; Botana, A.M.; Botana, L.M. New protocol to obtain spirolides from Alexandrium ostenfeldii cultures with high recovery and purity. Biomed. Chromatogr. 2010, 24, 878-886. 
69. Rodriguez, P.; Alfonso, A.; Botana, A.M.; Vieytes, M.R.; Botana, L.M. Comparative analysis of pre- and post-column oxidation methods for detection of paralytic shellfish toxins. Toxicon $\mathbf{2 0 1 0}$, $56,448-457$.

70. Otero, P.; Alfonso, A.; Alfonso, C.; Rodriguez, P.; Vieytes, M.R.; Botana, L.M. Effect of uncontrolled factors in a validated liquid chromatography-tandem mass spectrometry method question its use as a reference method for marine toxins: Major causes for concern. Anal. Chem. 2011, 83, 5903-5911.

71. Guisande, C.G.; Vaamonde, A.L.; Barreiro, A. Tratamiento de datos con R, Statistica y SPSS; Díaz de Santos: Madrid, Spain, 2011; p. 978.

(C) 2013 by the authors; licensee MDPI, Basel, Switzerland. This article is an open access article distributed under the terms and conditions of the Creative Commons Attribution license (http://creativecommons.org/licenses/by/3.0/). 